\title{
EFFECT OF CREATINE SUPPLEMENTATION DOSING STRATEGIES ON AGING MUSCLE PERFORMANCE
}

\author{
A Thesis \\ Submitted to the Faculty of Graduate Studies and Research \\ In Partial Fulfillment of the Requirements \\ For the Degree of \\ Master of Science \\ in \\ Kinesiology and Health Studies \\ University of Regina \\ By \\ Jennifer Anne Chami \\ Regina, Saskatchewan
}

November 2017

Copyright 2017: J. Chami 


\section{UNIVERSITY OF REGINA}

\section{FACULTY OF GRADUATE STUDIES AND RESEARCH SUPERVISORY AND EXAMINING COMMITTEE}

Jennifer Anne Chami, candidate for the degree of Master of Science in Kinesiology \& Health Studies, has presented a thesis titled, Effect of Creatine Supplementation Dosing Strategies on Aging Muscle Performance, in an oral examination held on November 9, 2017. The following committee members have found the thesis acceptable in form and content, and that the candidate demonstrated satisfactory knowledge of the subject material.

External Examiner:

Supervisor:

Committee Member:

Committee Member:

Chair of Defense:

*Via Skype

${ }^{* *}$ Not present at defense
*Dr. Trisha VanDusseldorp, Kennesaw State University

Dr. Darren Candow, Faculty of Kinesiology \& Health Studies

Dr. Paul Bruno, Faculty of Kinesiology \& Health Studies

${ }^{* *}$ Dr. Katherine McLeod, Adjunct

Dr. Donald Sharpe, Department of Psychology 


\begin{abstract}
Creatine supplementation has shown promise for increasing muscle strength, endurance and tasks of functionality in the aging population. However, the optimal dosage of creatine needed to maximize these potential benefits is unknown. The purpose of this study was to compare the effects of different dosages of creatine supplementation on aging muscle performance and functionality. Using a double-blind, repeated measures design, participants were randomized to one of three groups: Creatine-High $(\mathrm{CR}-\mathrm{H} ; \mathrm{n}=11 ; 59.3 \pm 3.2 \mathrm{yrs}, \mathrm{wt}=82.6$ $\pm 16.8 \mathrm{~kg}, \mathrm{BMI}=28.3 ; 0.3 \mathrm{~g} / \mathrm{kg} /$ day of creatine $+0.1 \mathrm{~g} / \mathrm{kg} /$ day of maltodextrin), Creatine-Low $(\mathrm{CR}-\mathrm{L}: \mathrm{n}=9 ; 58.8 \pm 5.9 \mathrm{yrs}, \mathrm{wt}=82.3 \pm 16.1 \mathrm{~kg}, \mathrm{BMI}=28.2 ; 0.1 \mathrm{~g} / \mathrm{kg} /$ day of creatine +0.3 $\mathrm{g} / \mathrm{kg} /$ day of maltodextrin) or Placebo (PLA; $\mathrm{n}=11 ; 57.3 \pm 4.6 \mathrm{yrs}, \mathrm{wt}=84.1 \pm 11.4 \mathrm{~kg}, \mathrm{BMI}=$ $28.8 ; 0.4 \mathrm{~g} / \mathrm{kg} /$ day of maltodextrin) for 10 consecutive days. The dependent variables measured at baseline and after supplementation were muscle strength (1-repetition maximum leg press, chest press, hand grip), muscle endurance (leg press and chest press; maximal number of repetitions performed at $80 \%$ and $70 \%$ baseline 1 - repetition maximum respectively), and tasks of functionality (walking speed, balance). There was a significant increase over time for leg press strength $(p=0.000)$, chest press strength $(p=0.001)$, leg press endurance $(p=0.001)$ and chest press endurance $(p=0.001)$, with no differences between groups. There were no changes over time between groups for right-hand grip strength $(\mathrm{p}=0.571)$, left-hand grip strength $(\mathrm{p}=$ $0.386)$, walking speed $(\mathrm{p}=0.226)$ or falls $(\mathrm{p}=0.414)$. In conclusion, short-term creatine supplementation, independent of dosage, has no effect on aging muscle performance. Creatine supplementation may have to be combined with resistance training to produce significant muscle health benefits in aging adults.
\end{abstract}

Keywords: Strength, Endurance, Balance, Falls, Aging 


\section{Acknowledgements}

I would like to thank my supervisor Dr. Darren Candow for his expertise, time and knowledge through this thesis process as well as my committee members, Dr. Paul Bruno and Dr. Katherine McLeod for their comments and input. I would like to thank my study participants for their time and energy spent on the study. I would also like to thank my husband and children who have been my support system and motivation to help me balance my commitment to them as well as this project, helping and encouraging me along the way. This thesis would not have been able to happen without your love, support and motivation. Thanks for making this possible. 


\section{Table of Contents}

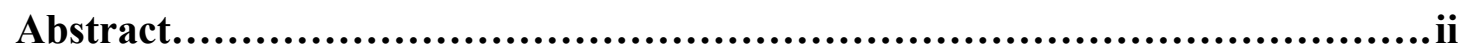

Acknowledgements.......................................................... iii

Table of Contents.............................................................iv

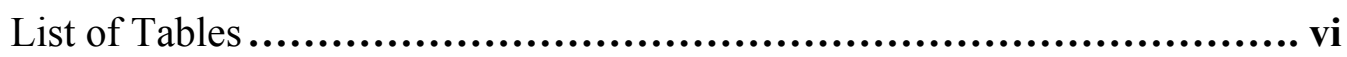

List of Abbreviations.............................................. vii

1 Introduction..........................................................................1

2 Literature review..............................................................3

2.1 Contributing factors of aging muscle loss........................... 3

2.1.1 Reduced muscle fiber.................................. 3

2.1.2 Anabolic resistance, protein and hormonal kinetics .............4

2.1.3 Nutrition................................................. 5

2.1.4 Reduced physical activity levels..........................6

2.1.5 High-energy phosphate metabolism........................6

2.1.6 Oxidative stress and mitochondrial dysfunction...............

2.1.7 Satellite cells...........................................8

2.1.8 Muscle Contraction................................... 8

2.2 Mechanistic Actions of Creatine......................................9

2.2.1 Creatine and energy metabolism.......................... 10

2.2.2 Creatine as a buffer.................................. 10

2.2.3 Creatine and muscle morphology $\ldots \ldots \ldots \ldots \ldots \ldots \ldots \ldots \ldots \ldots . \ldots 11$

2.2.4 Creatine and muscle protein kinetics $\ldots \ldots \ldots \ldots \ldots \ldots \ldots \ldots \ldots 12$

2.2.5 Creatine and anabolic secretion/signaling molecules ...........13

2.2.6 Creatine and satellite cell activity $\ldots \ldots \ldots \ldots \ldots \ldots \ldots \ldots \ldots \ldots \ldots \ldots$ 
2.2.7 Creatine and oxidative stress................................. 14

2.3 Effect of creatine supplementation on aging muscle...................... 14

2.3.1 Creatine dosage and duration ................................ 14

2.3.2 Creatine without exercise..................................... 16

3 Research purpose and hypothesis.............................................16

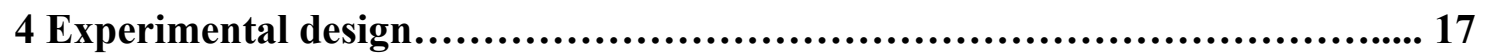

4.1 Participants.................................................................. 18

4.2 Primary dependent variables.................................................... 18

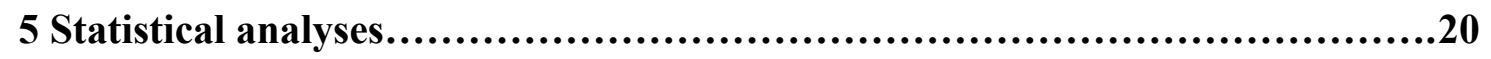

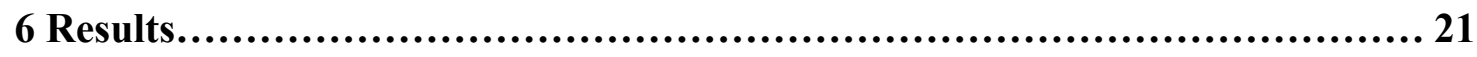

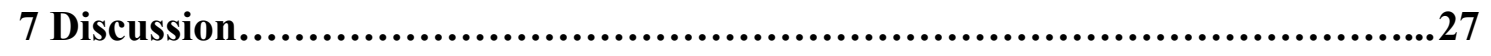

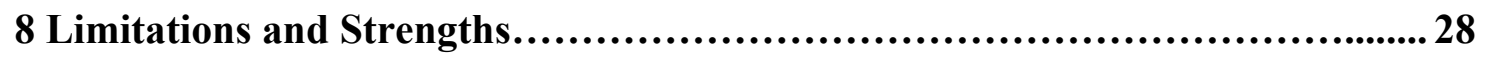

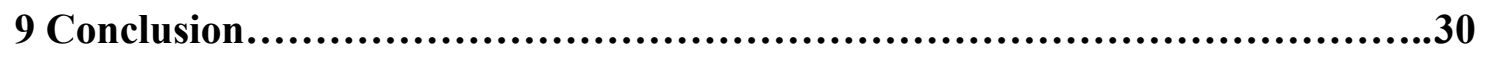

10 References..................................................................... 31

Appendix A: Leisure Time Exercise Questionnaire...........................................................51

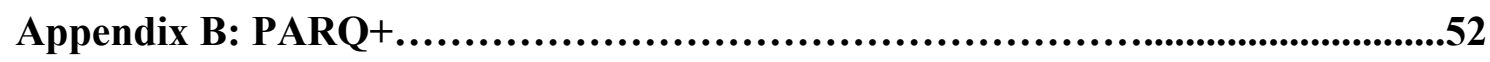

Appendix C: Research Participant Information and Consent .............................53

Appendix D: Adverse Event Form ........................................................58 


\section{List of Tables}

Table 1 Participant characteristics and supplement dosage for CR-H, CR-L, and PLA

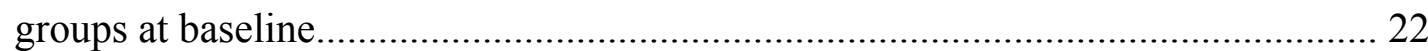

Table 2 Muscle strength (1-RM) and endurance (repetitions to volitional fatigue with $80 \% 1-\mathrm{RM}$ for leg press and 70\% baseline 1-RM for chest press) at baseline and

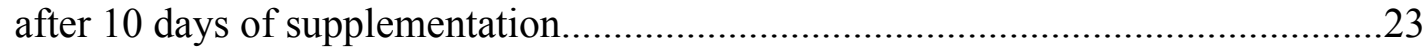

Table 3 Hand-grip strength $(\mathrm{kg})$ at baseline and after 10 days of

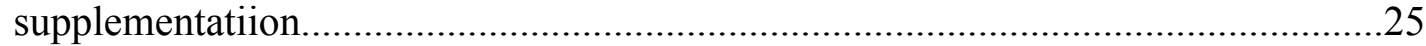

Table 4 Walking speed (seconds) and number of falls at baseline and after 10 days of supplementation. 26 


\section{List of Abbreviations}

1-RM One repetition maximum

AA Amino Acids

ACSM The American College of Sports Medicine

ADP Adenosine phosphate

ANOVA Analysis of Variance

ATP Adenosine triphosphate

BMI Body Mass Index

BBB Blood brain barrier

CK Creatine kinase

CNS Central nervous system

CR Creatine

CR-H High-dosage creatine

CR-L Low-dosage creatine

CRT Creatine transporter proteins

CSA Cross-sectional area

ERK6 Extracellular signal regulated kinase 6

g gram

Ht Height

i.e. that is

IGF-1 Insulin-like growth factor

IL-6 Pro inflammatory cytokines interleukin 6

kg kilogram 


\begin{tabular}{|c|c|}
\hline MAPK & mitogen-activated protein kinase \\
\hline MPB & Muscle protein breakdown \\
\hline mRNA & Messenger RNA \\
\hline mTOR & Mechanistic target of rapamycin \\
\hline RNA & Ribonucleic acid \\
\hline MPS & Muscle protein synthesis \\
\hline P38 MAPK & Mitogen activated protein kinase \\
\hline PAR-Q+ & Physical activity readiness questionnaire \\
\hline $\mathrm{PCr}$ & Phosphocreatine \\
\hline $\mathrm{PKB} / \mathrm{Akt}$ & Protein kinase B \\
\hline PLA & Placebo \\
\hline RDA & Recommended dietary allowance \\
\hline TNF- $\alpha$ & Tumor necrosis factor $\alpha$ \\
\hline $\mathrm{TC}$ & Total creatine \\
\hline $\mathrm{U}$ of $\mathrm{R}$ & University of Regina \\
\hline $\mathrm{Wt}$ & weight \\
\hline
\end{tabular}




\section{Introduction}

The age-related loss of muscle strength (i.e., maximum load that can be performed in a single repetition) and muscle endurance (i.e., maximum number of repetitions that can be performed to volitional fatigue) decreases functionality and our ability to perform activities of daily living (i.e., walking and carrying groceries; Short \& Nair, 2001). Muscle strength typically peaks in the third decade of life and remains reasonably constant until the fifth decade but then rapidly decreases at a rate of $12-15 \%$ for each subsequent decade thereafter (Hunter \& Bamman, 2004). Muscle endurance typically peaks in the second decade but also subsequently declines with aging (Nakao, Inoue, \& Murakami, 1989). Factors contributing to the decrease in muscle performance with aging may include changes in muscle morphology (Larsson et al., 2001), neuromuscular function (Bea et al., 2009), oxidative stress (Buford et al., 2010), endocrinology (Deschenes, 2004), nutrition and physical activity (Tipton, 2001). From a healthy aging perspective, interventions that improve aging muscle performance and functionality may be clinically significant.

One potential intervention that may benefit aging muscle health is creatine supplementation. Creatine is a naturally occurring nitrogen-containing compound found in the diet, primarily in red meat and seafood (Wyss \& Kaddurah-Daouk, 2000). The majority of creatine $(95 \%)$ is stored in skeletal muscle as phosphocreatine $(\mathrm{PCr})$, a high-energy phosphate involved in the rapid resynthesis of adenosine triphosphate (ATP) during intense muscle contraction (Wyss \& Kaddurah-Daouk, 2000). Unfortunately, aging may have a negative impact on high-energy phosphate metabolism and muscle performance (Candow \& Chilibeck, 2008). Creatine supplementation increases intramuscular creatine and aging muscle performance, however the dosage of creatine needed to produce these benefits is controversial. For example, Brose, Parise and Tarnopolsky (2003) found a significant increase in intramuscular total creatine and $\mathrm{PCr}$ which may have contributed to the greater gains in muscle strength in healthy 
older adults receiving low-dosage creatine supplementation ( $5 \mathrm{~g} /$ day or $\sim 0.07 \mathrm{~g} / \mathrm{kg} / \mathrm{day}$ ) during 14 weeks of resistance training compared to those receiving a placebo. Furthermore, low-dosage creatine $(0.1 \mathrm{~g} / \mathrm{kg} /$ day $)$ during resistance training (32 weeks) increased upper and lower body strength compared to placebo and resistance training in aging adults (Candow, Vogt, Johannsmeyer, Forbes, \& Farthing, 2015; Candow et al., 2008; Candow, Chilibeck, \& Forbes, 2014). A recent long-term study investigating the effects of low-dosage creatine $(0.1 \mathrm{~g} / \mathrm{kg} / \mathrm{day})$ during 1 year of resistance training in postmenopausal women showed that creatine had a positive effect on upper body strength but not lower body strength (Chilibeck, Candow, Landeryou, Kaviani, \& Paus-Jenssen, 2015). In addition, low-dosage creatine supplementation $(0.1 \mathrm{~g} / \mathrm{kg} /$ day $)$ during 11 weeks of resistance training had no effect on upper or lower body muscle strength in aging adults compared to placebo (Cooke et al., 2014). Speculation exists that these inconsistent findings across studies may partially be due to the lower dosage of creatine used.

The recent position stand paper by the International Society of Sports Nutrition on the safety and efficacy of creatine in exercise, sport and medicine indicates that clinical populations may need to consume 10-30 g/day of creatine throughout their lifespan to offset creatine synthesis deficiencies and/or provide therapeutic benefit in various disease states (Kreider et al., 2017). Therefore, higher creatine dosages may produce more consistent and greater muscle benefits in aging adults. For example, short-term, high-dosage creatine supplementation ( 0.3 $\mathrm{g} / \mathrm{kg} /$ day) for seven days significantly increased PCr (Solis et al., 2017), lower-body functional performance (Gotshalk et al., 2002) and capacity in aging adults (Canete et al., 2006; Gotshalk et al., 2002). In addition, high-dosage creatine supplementation ( $25 \mathrm{~g}$ per day for 5 days $)$ prior to performing single-leg knee extension repetitions to muscle fatigue resulted in a $30 \%$ increase in PCr, which correlated to a decrease in exercise fatigue in aging adults (Smith et al., 1985). 
Results across studies indicate that low-dosage and high-dosage creatine supplementation increases intramuscular creatine, which may subsequently benefit aging muscle performance. However, no study has compared the effects of low- vs. high-dosage creatine in healthy aging adults. The purpose of this thesis was to determine whether high-dosage creatine $(0.3 \mathrm{~g} / \mathrm{kg} /$ day $)$ produced greater muscle benefits compared to low-dosage creatine $(0.1 \mathrm{~g} / \mathrm{kg} /$ day $)$ in healthy aging adults for 10 consecutive days. Results from this thesis provide important information for the development of creatine supplementation protocols for aging muscle health.

\section{Literature Review}

\subsection{Contributing Factors of Aging Muscle Loss}

The mechanisms leading to aging muscle loss are unclear. Numerous suggested hypotheses include DNA damage (Barazzoni, Short, \& Nair, 2000), reduced protein synthesis (Proctor, Balagopal, \& Nair, 1998), muscle fiber type changes (Lexell, 1995), inactivity (Evans, 1995), inadequate nutrition (Campbell \& Evans, 1996; Roberts, 1995), and hormonal changes (Dionne, Kinaman, \& Poehlman, 2000).

2.1.1 Reduced muscle fiber. Muscle loss generally occurs after 40 years of age and rapidly accelerates after 70 years of age (Lexell, Henriksson-Larsen, Winblad, \& Sjostrom, 1983). This has been demonstrated in autopsy analyses of men 70-73 years of age who had approximately 110,000 less muscle fibers in the midsection of the vastus lateralis than younger men (19-37 years of age), yielding a 23\% decline in muscle fiber content. Furthermore, 80 year-old males possessed 30\% less type II muscle fibers than their younger counterparts (Lexell et al., 1983).

The loss of muscle fibers with aging is partially due to the loss of alpha motor neurons, which innervate muscle fibers (Agaard, Suetta, Caserotti, Magnusson, \& Kjaer, 2010; Lexell, 1997). During the aging process, there is a rearrangement of motor unit fibers and an increased number of muscle fibers per motor unit area (Larsson \& Salviati, 1989). Consequently, the 
total number of muscle fibers typically decreases, indicating a denervation-reinnervation process (Ansved \& Edstrom, 1991). Changes in myofibrillar protein isoform expression have also been observed in both slow-twitch and fast-twitch muscles. There appears to be a gradual decrease in fast-twitch (i.e., type II) muscle fibers with aging, which precedes the age-related loss of total muscle fiber number (Ansved \& Larsson, 1989). There is also an increased number of intermediate (i.e., type IIa) and slow-twitch muscle fibers (i.e., type I; Larsson \& Edstrom, 1986), which inevitably compromises force production (Hepple, 2003). Therefore, this combination of muscle and force loss with aging may be caused by a reduction in muscle fiber number (Hepple, 2014; Trappe, 2001) and by fiber atrophy, particularly among type II fibers (Larrson et al., 2001).

2.1.2 Anabolic resistance, protein and hormonal kinetics. Skeletal muscle is a dynamic tissue that undergoes constant protein turnover (i.e., protein breakdown and protein synthesis). Aging muscle loss can occur from anabolic resistance (i.e., decreased response to dietary protein and resistance training; Rennie \& Tipton, 2000). Muscle mass is maintained from the balance of muscle protein breakdown (MPB) and muscle protein synthesis (MPS). For muscle hypertrophy to proceed, the rate of MPS must be greater than the rate of MPB (Rennie \& Tipton, 2000). Therefore, muscle loss occurs when there is an imbalance between MPS and MPB. During the aging process, there is accelerated protein breakdown (i.e., whole-body, mixed- muscle) that results in muscle tissue atrophy (Karakelides \& Nair, 2005; Marcell, 2003) and subsequent infiltration of fat and connective tissue. In older adults, this may be due to a decreased sensitivity to amino acids, insulin, or both (Combaret et al., 2009); a reduced basal rate of mitochondrial protein synthesis (Balagopal, Schimke, Ades, Adey, \& Nair, 2001; Rooyackers, Adey, Ades, \& Nair, 1996); a decrease in anabolic hormone production of testosterone (Baumgartner, Waters, Gallagher, Morley, \& Garry, 1999), growth hormone (GH) (Welle, Thornton, Statt, \& McHenry, 1996), and insulin growth factor-1 (IGF-1) (Butterfield et 
al., 1997); or an increase in cortisol (Marcell, 2003). As a result, the capacity of skeletal muscle to incorporate amino acids (AA) into muscle proteins is inhibited (Deschenes, 2004).

2.1.3 Nutrition. Malnutrition and protein deficiency cause the loss of lean body mass (Singh, 2000). Consequently, adequate protein intake is important for maintaining the balance between protein synthesis and breakdown. The current recommended dietary allowance (RDA) for protein is $0.8 \mathrm{~g} / \mathrm{kg} / \mathrm{day}$, which itself may represent a minimal requirement for populations such as the aging (Campbell, Trappe, Wolfe, \& Evans, 2001; Wolfe, Miller, \& Miller, 2008). Approximately $15-38 \%$ of adult men and $27-41 \%$ of adult women have dietary protein intakes below the current RDA of $0.8 \mathrm{~g} / \mathrm{kg}$ /day (Campbell et al., 2001). It has been shown that a higher protein intake may provide greater benefits for maintaining muscle mass in an aging population (Wolfe, Miller, \& Miller, 2008). In particular, it has been suggested that the stimulatory effects of essential AA to initiate MPS decrease with aging(Breen \& Phillips, 2011; Wolfe et al., 2008). Increasing the dietary protein intake by a moderate amount above the RDA may enhance muscle protein growth and reduce the progressive loss of muscle mass with age (Campbell et al., 2001; Paddon-Jones, Short, Campbell, Volpi, \& Wolfe, 2008). This resistance toward anabolic stimuli may contribute to the overall reduction of muscle protein balance. Thus, the supplementation of AA, especially the branched-chain AA leucine, may have beneficial effects to maintain and/or increase muscle mass (Candow et al., 2012). Leucine appears to be a key metabolic regulator for the activation of the mTOR (mechanist target of rapamycin) signaling pathway and the initiation of MPS in the elderly (Atherton, Smith, Etheridge, \& Rankin, 2010; Kimball \& Jefferson, 2006; Rieu et al., 2006).

Research on the effects of protein with resistance training in the aging population has not been very clear (Andrews, MacLean, \& Riechman, 2006; Campbell, 2007; Iglay, Thyfault, Apolzan, \& Campbell, 2007). A study by Iglay et al. (2007) compared 36 older men and women with lower protein $(0.9 \mathrm{~g}$ protein $/ \mathrm{kg} /$ day $)$ versus higher protein $(1.2 \mathrm{~g}$ protein $/ \mathrm{kg} / \mathrm{day})$ 
intake along with 12 weeks of resistance training. Although all outcome measures improved (i.e., increased strength, greater whole-body protein accretion, and reduced fat mass), there were no significant differences between the groups with lower protein or higher protein intake. Similarly, Andrews et al. (2006) found that total daily protein intake (1.35 versus 0.72 $\mathrm{g} / \mathrm{kg} /$ day) did not affect lean mass gains in the context of post-exercise protein supplementation.

2.1.4 Reduced physical activity levels. Physical activity typically declines with age (Herndon et al., 2002; Kirkwood \& Finch, 2002). A decrease in muscle mass and muscle strength, in combination with reduced endurance, causes reduced physical activity (Nair, 2005). Muscle mass is responsible for approximately 30\% of resting energy expenditure and protein turnover and 70\% of body cell mass (Nair, 2005). Physical activity levels are responsible for about $10-60 \%$ of daily energy expenditure (Nair, 2005). When muscle mass and physical activity are reduced, there is a decrease in total energy expenditure that may contribute to chronic health conditions (Nair, 2005).

2.1.5 High-energy phosphate metabolism. $\mathrm{PCr}$ appears to play an important role in muscle metabolism. Intramuscular PCr allows PCr to function optimally as an ATP buffer under conditions in which oxidative phosphorylation and glycolysis cannot provide the necessary energy supply (Siegman \& Butler, 1985). Therefore, ATP concentrations are maintained when adenosine diphosphate (ADP) and PCr are high (Siegman \& Butler, 1985). There is controversy whether creatine stores are reduced and PCr metabolism is affected with aging. Some studies show reduced creatine stores in aging adults and slower PCr hydrolysis/kinetics during and after exercise (Forsberg, Nilsson, Werneman, Bergström, \& Hultman, 1991; McCully, Fielding, Evans, Leigh, \& Posner, 1993; McCully et al, 1991; Smith et al, 1985) while others indicate no differences (Chilibeck et al., 1998; Kent-Braun 1985) or even higher PCr stores in aging adults (Rawson, Clarkson, Price, \& Miles, 2002). These inconsistences may be attributed to 
fitness/training status. For example, the older participants in the study by Chilibeck et al (1998) had a slightly higher fitness levels (moderate) compared to the participants used in the study by McCully et al (1993) resulting in faster PCr kinetics. Another possibility could be that the moderately active participants had not reached an age where PCr kinetics became slower (Chilibeck et al., 1998) or that even modest activity is adequate to maintain a functional muscle oxidative capacity (Kent-Braun, 1985).

2.1.6 Oxidative stress and mitochondrial dysfunction. A decrease in oxidative homeostasis may also contribute to aging muscle loss (Johnston, De Lisio, \& Parise, 2008). The oxidative stress theory of aging suggests that there is a progressive cellular decline with aging due to the buildup of damage by mutagenic oxygen radicals to cells, resulting in cellular deterioration (Johnston et al., 2008; Sohal \& Weindruch, 1996). An increase in oxidative damage upregulates antioxidant systems, and with aging, these systems may not be able to combat the demands of the oxidative cellular stress. Cytokines are then released in response to chronic inflammation and stress. With aging there is an accelerated increase in the release of the proinflammatory cytokines interleukin 6 (IL-6) and tumor necrosis factor- $\alpha$ (TNF- $\alpha$ ), which results in muscle atrophy, loss of strength (Ladner, Caligiuri, \& Guttridge, 2003), and MPB (Bales \& Ritchie, 2002). Mitochondrial dysfunction may be a cause of declining physical activity levels. There is increasing evidence in rodents (Barazzoni, Short, \& Nair, 2000) and in humans (Rooyackers Adey, Ades, \& Nair, 1996) that muscle mitochondrial dysfunction occurs with age. The changes in muscle mitochondrial function include decreases in mitochondrial DNA copy numbers, decreases in mRNA (messenger RNA) concentrations in genes encoding muscle mitochondrial proteins (Barazzoni et al., 2000; Short et al., 2003), reduced muscle mitochondrial oxidative enzyme activities, and reduced mitochondrial protein synthesis rates. Muscle mitochondrial ATP production also decreases with age (Lanza \& Nair, 2009). 
2.1.7 Satellite cells. Satellite cells are mononucleiated cells that reside between the basal lamina and sarcolemma (Mauro, 1961). They appear to have a finite lifespan and undergo replication in the last stage of post-embryonic development (Gopinath \& Rando, 2008). Satellite cells are essential for muscle growth, repair, and maintenance (Hawke \& Garry, 2001; Mauro, 1961). Once activated, they produce muscle precursor cells, which undergo activation, proliferation, and differentiation to form new muscle fibers (Ryall, Schertzer, \& Lynch, 2008). Aging appears to have a negative effect on satellite cell function and quality (Brack \& Rando, 2007). A loss of satellite cell proliferation could potentially limit aging muscle growth, especially if satellite cells proliferative potential is exhausted during a lifespan of repeated cycles of growth and regrowth (Chakravarthy, Spangenburg, \& Booth, 2001). In addition, aging satellite cells show a delayed response to mechanical stimuli and are susceptible to cellular death (Jejurikar et al., 2006). Research also has shown a substantial reduction in the number of active satellite cells in type II, but not type I, fibers of the vastus lateralis in older adults (Verdijk et al., 2007), suggesting that satellite cell growth with age is fiber specific, which may help explain the reduction in type II muscle fibers.

2.1.8 Muscle contraction. The age-related slowing of both fast-twitch and slow-twitch muscle fibers is thought to be caused by structural (Decoster, Reuck, Sieben, \& Eecken, 1981), functional (Larsson \& Salviati, 1989), and biochemical (Viner, Huhmer, Bigelow, \& Schoneich, 1996) changes in the sarcoplasmic reticulum. Sarcoplasmic reticulum properties are the strongest determinants of speed of contraction, whereas myosin heavy chain isoforms influence maximum shortening velocity (Brody, 1976). It has been shown that the aging process has a negative effect on sarcoplasmic reticulum protein quality and function (Larsson et al., 2001), resulting in a decline in maximum contractile force in skeletal muscle. Furthermore, there is a significant reduction in myosin per muscle fiber volume with age (Thompson, 2009). Myosin is the main myofibrillar protein responsible for force production in skeletal muscle. This was shown by 
Larsson et al. (2001), who found a two-fold decrease in speed of contraction between old and young isolated muscle fibers in rats, suggesting an accelerated decline in myosin function with aging.

\subsection{Mechanistic Actions of Creatine}

Creatine is a nitrogenous organic compound found in all cells in the body. It is synthesized in the kidney, liver, and pancreas by the amino acids arginine, glycine, and methionine before it enters the bloodstream (Adhihetty \& Beal, 2008; Bloch \& Schoenheimer, 1941; Tarnopolsky \& Beal, 2001; Wyss \& Kaddurah-Daouk, 2000). Once in the bloodstream, plasma creatine is transported into the cells via creatine transporter proteins (CRT) (Christie, 2007; Lowe, 2015). This transport is critical for the distribution of creatine throughout the cells as well as its ability to transverse the blood brain barrier (BBB), which gives creatine access to the central nervous system (CNS) (Adhihetty \& Beal, 2008; Bloch \& Schoenheimer, 1941; Christie, 2007; Lowe, Faull, Christie, \& Waldvogel; Tarnopolsky, 2001). Approximately 95\% of the body's creatine is stored in skeletal muscle, of which $\sim 40 \%$ is free $\mathrm{Cr}$ and $60 \%$ is $\mathrm{PCr}$ (Balsom, Soderlund, \& Ekblom, 1994; Heymsfield, Arteaga, McManus, Smith, \& Moffitt, 1983; Walker, 1979). The remaining 5\% is found in the brain, liver, testes, and kidneys (Persky \& Brazeau, 2001; Walker, 1979). The total creatine pool ( $\mathrm{PCr}+$ free creatine) in skeletal muscle averages about $120 \mathrm{~g}$ for a $70 \mathrm{~kg}$ individual. However, the average human has the capacity to store up to $160 \mathrm{~g}$ of creatine under certain conditions (Greenhaff, 1997; Hultman, Bergstrom, Spreit, \& Soderlund, 1990). The body metabolizes about $1-2 \%$ of its creatine stores per day to creatinine (Brunzel, 2003). Therefore, 1-3g of dietary creatine is required to maintain intramuscular creatine stores. Creatinine is then filtered by the kidneys by simple diffusion and excreted in the urine (Brunzel, 2003; Burke, 2001). Creatine stores can be replenished by obtaining creatine in the diet or through endogenous synthesis of creatine from glycine, arginine, and methionine (Williams \& Branch, 1998; Williams, Kreider, \& Branch, 1999). 
2.2.1 Creatine and energy metabolism. One of the most popular mechanisms to explain the efficacy of creatine supplementation is the enhancement of the PCr energy system, which allows users to maintain a greater work intensity for longer durations of time (i.e., increased total training volume). The PCr energy system is involved in high-intensity exercise performance (Kraemer \& Volek, 1999; Kreider et al., 1998) as well as the shuttling of highenergy phosphates between the mitochondria and cytosol via the creatine phosphate shuttle (Bessman \& Savabi, 1988; Kreider, 2003; Wallimann et al., 1998). An increase in intramuscular creatine content by exogenous creatine ingestion would increase $\mathrm{PCr}$ resynthesis during intense muscle contraction and could potentially enhance muscle performance (Balsom et al., 1995; Greenhaff, Bodin, Soderland, \& Hultman, 1994; Harris, Soderlund, \& Hultman, 1992).

2.2.2 Creatine as a buffer. $\mathrm{PCr}$ was first isolated from muscle tissue in 1927 and free creatine was generated from its breakdown during muscle contraction (Fiske \& Subbarow, 1927). The common function of PCr is a temporal energy buffer during periods of rapid ATP turnover (i.e., exercise; Volek \& Kraemer, 1996). PCr acts to buffer rapid increases in hydrogen ions $(\mathrm{H}+)$, which are by-products of ATP hydrolysis during intense muscle contraction (Volek, Ballard, \& Forsythe, 2008). The breakdown of PCr involves the uptake of protons, which has acid-base implications because it counteracts the acidosis or acidification of cells (Henriksson \& Sahlin, 2003; Volek et al., 2008).

Creatine maintains the intracellular levels of ATP in skeletal muscle during muscle contraction. During the initial stages of muscle contractions, ATP is rapidly degraded to generate Adensosine Phosphate (ADP) and inorganic phosphate (Pi; see Rx \#1; Volek et al., 1999; Wallimann et al., 1998; Wallimann, Wyss, Brdiczka, Nicolay, \& Eppenberger, 1992). PCr serves as an energy buffer via its participation in the reversible creatine kinase $(\mathrm{CK})$ reaction that acts to replenish ATP during intense exercise (Volek et al., 1999; see Rx \#2). Eventually, $\mathrm{PCr}$ concentrations decline and more reliance on glycolytic and aerobic energy 
metabolite sources occurs. This reaction occurs rapidly and reversibly via the enzyme CK, making the ATP replenishing capacity of both PCr and creatine kinase high. Conversely, at rest, $\mathrm{PCr}$ is resynthesized by ATP, donating a phosphate group to creatine in order to replenish PCr stores for future muscle contraction use (see Rx \#3; Volek et al., 2008; 1999).

$$
\begin{aligned}
& \mathrm{Rx} \# 1 \text { (Exercise): } \mathrm{ATP} \rightarrow(\text { ATPase }) \rightarrow \mathrm{ADP}+\mathrm{Pi} \\
& \mathrm{Rx} \# 2 \text { (Exercise): } \mathrm{PCr}+\mathrm{ADP}+\mathrm{H}+\rightarrow(\text { creatine kinase }) \rightarrow \mathrm{Cr}+\mathrm{ATP} \\
& \mathrm{Rx} \# 3 \text { (Recovery): } \mathrm{PCr}+\mathrm{ADP}+\mathrm{H}+\leftarrow(\text { creatine kinase }) \leftarrow \mathrm{Cr}+\mathrm{ATP}
\end{aligned}
$$

During sustained high-intensity exercise, the $\mathrm{CK}$ reaction acts as an important $\mathrm{pH}$ buffer, which accounts for approximately $30-40 \%$ of the total intracellular metabolic buffer capacity (Henriksson et al., 2003; Rossiter, Cannell, \& Jakeman, 1996). Consequently, higher PCr concentrations may help prolong fatigue by maintaining normal $\mathrm{pH}$ levels (Cramer, 2008).

2.2.3 Creatine and muscle morphology. A reduction in cross-sectional area (CSA) of type II fibers is primarily responsible for the decrease in muscle mass with aging, which was proven in a biopsy study that found a $15-25 \%$ decrease in type IIA and type IIB muscle fiber CSA (Coggan et al., 1990). Creatine supplementation may help in the retention of type II skeletal muscle fibers with age, as research has suggested that creatine supplementation may be able to promote muscle hypertrophy through a variety of mechanisms, including cell swelling (Berneis, Ninnis, Haussinger, \& Keller, 1999) which may act as a signal to reduce whole-body proteolysis and AA oxidation (Berneis et al., 1999), alter the expression of myogenic transcription factors (Hespel et al, 2001; Ingwal, 1976), increase satellite cell mitotic activity (Dangott, Schultz, Mozdziak, 2000; Olsen et al., 2006), and allow for increased exercise volume due to enhanced rates of ATP regeneration as a result of extending the duration of the PCr energy system (Casey, Constantin-Teodosiu, Howell, Hultman, \& Greenhaff, 1996; Rawson \& Volek, 2003). Dalbo et al., 2009 reported that creatine 
supplementation increased type II skeletal muscle fiber diameter independent of a training regime. Creatine supplementation, in combination with resistance training, has also been shown to increase muscle fiber CSA (Kreider et al., 1998; Volek et al., 1999).

Creatine may have a beneficial effect on muscle strength/endurance by increasing $\mathrm{PCr}$ and total creatine (TC) energy stores in muscle (Devries \& Phillips, 2014; Finn et al., 2001; Greenhaff et al., 1994; Harris et al., 1992; Volek et al., 1999; Williams \& Branch, 1998), increasing calcium reuptake into the sarcoplasmic reticulum, which would result in faster detachment of the actin-myosin cross- bridge and potentially augment force generating capacity (Bazzucchi, Felici, \& Sacchetti, 2009) and reduce muscle damage (Lefavi et al, 1998).

2.2.4 Creatine and muscle protein kinetics. $\mathrm{PCr}$ may also stimulate protein synthesis (Strumia, Pelliccia, \& D'Ambrosio, 2012). Creatine is an osmotically active compound; increases in total creatine content have been linked to increases in water retention. This may partly explain body mass increases of $1-2 \mathrm{~kg}$ after a creatine loading phase of 5-7 days (Willoughby \& Rosene, 2003). This increased cell volume appears to act as an anabolic signal that may enhance protein synthesis (Willoughby \& Rosene, 2003). Research has shown that cellular hydration affects protein synthesis in liver cells, whereas cell swelling stimulates-and cell shrinkage inhibits - protein synthesis (Häussinger, 1996). Although cell hydration and cell function have been most extensively studied in liver cells, it appears that these regulatory mechanisms occur in other cell types as well (Häussinger, 1996). Leucine flux is an indicator of whole body protein breakdown, which was measured after men and women consumed $20 \mathrm{~g}$ of creatine for 5 days, followed by $5 \mathrm{~g}$ for $3-4$ days. Creatine supplementation reduced the rates of leucine oxidation and protein breakdown in men, suggesting that creatine supplementation may provide an anti-catabolic effect on lean tissue in males (Parise, Mihic, MacLennan, Yarasheski, \& Tarnopolsky, 2001). In addition, Candow et al. (2008) 
demonstrated that low-dose creatine supplementation $(0.1 \mathrm{~g} / \mathrm{kg} /$ day $)$ reduced muscle protein catabolism in healthy adults $>50$ years of age.

\subsubsection{Creatine and anabolic hormone secretion/signaling molecules. Creatine}

supplementation may improve anabolic hormone secretion (Candow et al., 2012). For example, short-term creatine supplementation for 10 days (20 g/day for 3 days; $5 \mathrm{~g} /$ day for 7 days) upregulated the expression of genes and proteins that are involved in the synthesis of protein and glycogen, as well as satellite cell proliferation in young, healthy men (Safdar, Yardley, Snow, Melov, \& Tarnopolsky, 2008). In particular, muscle kinases p38 MAPK (mitogen-activated protein kinase), ERK6 (extracellular signal-regulated kinase 6), and $\mathrm{PKB} /$ Akt (protein kinase B) were shown to be significantly elevated. Moreover, 5 days of creatine supplementation ( $21 \mathrm{~g} /$ day) in young men increased IGF-1 and mRNA expression at rest and the phosphorylation of anabolic signaling molecules (i.e., mTOR) downstream target 4E-BP1) 24 hours after a bout of high-intensity resistance exercise (Deldicque et al., 2005). Another study showed greater increases in intramuscular IGF-1 content in healthy men and women after 8 weeks of resistance training combined with creatine supplementation, compared to placebo ingestion (Burke et al., 2008).

2.2.6 Creatine and satellite cell activity. Satellite cells sit between the basal lamina and sarcolemma (i.e. muscle fibre membrane) of muscle fibres and are involved in development of new muscle fibres or, in adult muscle, repair of damaged muscle fibres. Satellite cells donate their nuclei to muscle fibres, increasing the capacity for protein synthesis within the muscle fibre. Creatine supplementation appears to affect satellite cell activity and muscle hypertrophy (Candow et al., 2012; Volek et al., 2008). For example, Olsen et al. (2006) showed that 16 weeks of heavy resistance training combined with creatine supplementation $(6 \mathrm{~g}$ creatine $+14 \mathrm{~g}$ carbohydrate per day) increased the number of satellite cells at Weeks 4 and 
8. Additionally, the authors found a greater number of myonuclei, which were associated with the increase in muscle fiber CSA, in the creatine group.

2.2.7 Creatine and oxidative stress. PCr may protect against oxidative damage (Strumia et al., 2012). Animal studies showed that markers of oxidative stress in plasma and muscles were lower in rats that ingested creatine after acute aerobic exercise. In addition, the antioxidative capacity of creatine-supplemented rats increased significantly, which may indicate the beneficial effects of creatine supplementation on the antioxidative system (Deminice \& Jordao, 2011). These results are further supported by other studies that found creatine to have protective effects against tissue damage (Sestili, Martinelli, Colombo, Barbieri, \& Potenza, 2011). Creatine thus appears to protect mtDNA as well as preserve the integrity of mitochondria, and it may also protect ribonucleic acid (RNA) from oxidative damage (Sestili et al., 2011).

\subsection{Effect of Creatine Supplementation on Aging Muscle}

During the aging process there is an age-related decline in muscle strength, endurance, and functional performance. These negative consequences of aging increase the importance of identifying interventions which may help preserve or increase aging muscle health (Devries \& Phillips, 2014). Two meta-analyses have determined that creatine supplementation ( $>6$ weeks) during resistance training is effective for improving muscular strength and functionality compared to resistance training without creatine supplementation in aging adults $(>45-50$ years of age) (Candow et al., 2014; Devries and Phillips, 2014).

2.3.1 Creatine Dosage. The dosage of creatine needed to produce significant gains in aging muscle performance and functionality is controversial. For example, Brose et al. (2003) found a significant increase in muscle strength from low-dosage creatine supplementation ( 5 $\mathrm{g} /$ day or $\sim 0.07 \mathrm{~g} / \mathrm{kg} /$ day) during 14 weeks of resistance training in healthy aging adults. Furthermore, low-dosage creatine $(0.1 \mathrm{~g} / \mathrm{kg} / \mathrm{day})$ during resistance training (32 weeks) increased 
upper and lower body strength compared to placebo and resistance training in aging adults (Candow et al., 2015). A recent long-term study investigating the effects of low-dosage creatine $(0.1 \mathrm{~g} / \mathrm{kg} /$ day $)$ during 1 year of resistance training in postmenopausal women showed that creatine had a positive effect on upper body strength but not lower body strength (Chilibeck et al., 2015). In addition, low-dosage creatine supplementation $(0.1 \mathrm{~g} / \mathrm{kg} /$ day $)$ during 12 weeks of resistance training had no effect on upper or lower body muscle strength in aging adults compared to placebo (Cooke et al., 2014). Speculation exists that these inconsistent findings across studies may partially be due to the lower dosage of creatine used.

The recent position stand paper by the International Society of Sports Nutrition on the safety and efficacy of creatine in exercise, sport and medicine indicates that clinical populations may need to consume 10-30 g/day of creatine throughout their lifespan to offset creatine synthesis deficiencies and/or provide therapeutic benefit in various disease states (Kreider et al, 2017). Therefore, higher creatine dosages may produce more consistent and greater muscle benefits in aging adults. For example, short-term, high-dosage creatine supplementation $(0.3$ $\mathrm{g} / \mathrm{kg} /$ day) for seven days significantly increased PCr (Solis et al., 2017), lower-body functional performance (Gotshalk et al., 2002) and capacity in aging adults (Canete et al., 2006; Gotshalk et al., 2002). In addition, high-dosage creatine supplementation ( $\sim 25 \mathrm{~g}$ per day for 5 days $)$ prior to performing single-leg knee extension repetitions to muscle fatigue resulted in a $30 \%$ increase in PCr, which correlated to a decrease in exercise fatigue in aging adults (Smith et al., 1985).

Results across studies indicate that low-dosage and high-dosage creatine supplementation increases intramuscular creatine which may subsequently benefit aging muscle performance. However, no study has compared the effects of low- vs. high-dosage creatine in healthy aging adults.

2.3.2 Creatine without exercise. Research examining the effects of creatine supplementation, independent of exercise, is limited. Safdar et al. (2008) assessed a global array 
of mRNAs (to assess which proteins are transcribed) and proteins in response to 10 days of creatine supplementation (i.e. $20 \mathrm{~g} / \mathrm{d}$ for $3 \mathrm{~d} ; 5 \mathrm{~g} / \mathrm{d}$ for 7 days) in the vastus lateralis of young men. Proteins involved in sensing changes in osmolarity and signal transduction were upregulated with creatine supplementation, along with proteins involved in satellite cell proliferation and differentiation. Stout et al. (2007) showed that 14 days of creatine supplementation ( $20 \mathrm{~g} /$ day for 7 days followed by $10 \mathrm{~g}$ /day for 7 days) increased hand-grip strength and physical working capacity in elderly men and women. Furthermore, Rawson et al. (1999) showed that 30 days of creatine supplementation ( $20 \mathrm{~g}$ for 10 days followed by $4 \mathrm{~g}$ for 20 days) reduced lower-body muscle fatigue (an indicator of muscle endurance) in elderly men (60-82 years of age) but no improvements in body composition or strength were observed. Results across studies suggest that aging adults may experience muscle health benefits from creatine supplementation alone.

\section{Research Purpose and Hypothesis}

The purpose of this thesis was to compare the effects of different dosages of creatine on muscle strength, endurance, and tasks of functionality in aging adults.

It was hypothesized that high-dosage creatine $(0.3 \mathrm{~g} / \mathrm{kg} /$ day $)$ would improve muscle strength, endurance, balance, and walking speed after 10 consecutive days compared to lowdosage creatine $(0.1 \mathrm{~g} / \mathrm{kg} / \mathrm{day})$. It was also hypothesized that creatine supplementation, independent of dosage, would be superior to placebo.

\section{Experimental Design}

A priori power analysis $\left(\mathrm{G}^{*}\right.$ Power v. 3.1.5.1) showed that 42 participants were required. This calculation was based on a moderate effect size (Cohen's $d=0.25)$, an alpha level of .05, a $\beta$ value of 0.8 for a repeated measures: within-between interactions, ANOVA approach (Faul, Erdfelder, Lang, \& Buchner, 2007). 
The study was a double-blind, repeated measures design. Participants were matched according to age and gender and then randomized using a 1:1:1 strategy to one of three groups: Creatine-High (CR-H), Creatine-Low (CR-L), or Placebo (PLA) for 10 consecutive days (Table 1). A research assistant was responsible for randomizing the participants to groups to ensure all participants and investigators remained blinded throughout the study. Contents of the creatine monohydrate powder (Creapure, AlzChem AG, Trostberg, Germany) were verified by testing in an independent laboratory (The Cary Company, Addison, Ill., USA; creatine purity > 99.9\%). Creatine and placebo (Globe Plus 10 DE Maltodextrin, Univar Canada) were similar in taste, texture, color, and appearance. A research assistant was responsible for mixing and packaging the supplements and preparing individual study kits. Each study kit contained 10 daily plastic bags and detailed supplementation instructions which were placed in a large opaque envelope. Participants were instructed to consume their supplement in 2-3 equal dosages throughout the day with food or drink. Creatine dosages, on average, were approximately 8-25 g/day or 80-250 g over the duration of the study. Most typical creatine loading phases which increase muscle total creatine stores amount to 100-140 g of creatine over 5-7 days (Kreider et al., 2017). Justification for the 10 day supplementation protocol was based on the cellular findings in young adults of Safar et al. (2008) who found that 10 days of creatine (95 $\mathrm{g}$ in total) increased proteins involved in sensing changes in osmolarity and signal transduction and satellite cell proliferation and differentiation.

4.1 Participants. Males and females ( $\geq 50$ years of age) who were not engaged in supervised resistance training for $\geq 6$ weeks prior to the start of the study were recruited. Recruitment occurred through email using the University of Regina email server lists and posters placed throughout the University of Regina. Prior to the start of the study, participants filled out a leisure time exercise questionnaire, which indicated the average number of times that strenuous (i.e., heart beats rapidly), moderate (i.e., not exhausting), and mild exercise (i.e., 
minimal effort) was performed per week (Godin \& Shephard, 1985) (Appendix A). Participants also completed a Physical Activity Readiness Questionnaire (PAR-Q+). The questionnaire included questions related to chronic medical conditions (Appendix B). Participants were excluded if they had taken medications that affect muscle biology or creatine monohydrate $\leq 12$ weeks prior to the start of the study; if they had a history of fragility fractures; if they had diseases that are known to affect muscle biology (i.e., Crohn's Disease); if they suffered from severe osteoarthritis; or if they were vegetarian. Furthermore, participants with pre-existing kidney or liver abnormalities were excluded. Participants were instructed not to change their diet or physical activity patterns that were part of their daily routine during the study. In addition, participants were instructed to refrain from consuming nonsteroidal anti-inflammatory drugs during the study as these interventions can affect muscle protein and muscle recovery (Trappe et al., 2002). The study was approved by the Research Ethics Board at the University of Regina (Appendix C).

4.2 Primary Dependent Variables. The primary dependent variables measured at baseline and after supplementation were muscle strength (1-RM leg press, chest press, hand grip), muscle endurance (maximal number of repetitions performed at $80 \%$ and $70 \%$ baseline 1 RM for the leg press and chest press, respectively), and tasks of functionality (walking speed, balance). Participants performed a familiarization trial of strength and endurance as well as tasks of functionality at least 96 hours prior to baseline assessments. The familiarization trial helped reduce the amount of learning which may contribute to the outcome measures.

\section{Muscle Strength and Endurance}

Leg press and chest press strength was assessed using a 1-RM standard testing procedure in the Aging Muscle and Bone Health Laboratory, University of Regina. To measure the 1-RM leg press, a bilateral leg press machine was used. Participants were positioned in the leg press so that a $90^{\circ}$ angle at the knee was achieved and the feet were 
placed shoulder width apart. Each participant was instructed to push the weight away from his or her body to full extension without locking the knees before returning to the starting position. Following 5 minutes of cycling on a stationary cycle ergometer at a self-selected intensity, participants performed two warm-up sets in order: 1 set of 10 repetitions using a weight determined by each participant to be comfortable and 1 set of 5 repetitions using increased weight. Two minutes following the warm-up sets, weight was progressively increased for each subsequent 1-RM attempt with a 2-minute rest interval between attempts. For the 1-RM chest press, participants were positioned in a bilateral chest press machine with both feet on the floor. Following a demonstration, participants were instructed not to lift their buttocks off the bench or arch their backs during the lift. Participants were positioned in the chest press machine so that the adjacent bars lined up at mid-chest level. Participants were instructed to grasp the bars (overhand grip) at approximately shoulder width apart and push the weight away from the body until full extension and then lower the weight back to the starting position. Five minutes of rest separated the determination of 1-RM leg press and chest press strength.

Handgrip strength was measured using a handgrip dynamometer. Participants performed two attempts for each hand with the best attempt recorded for each hand. For convenience, handgrip strength was measured when the tasks of functionality were assessed.

Leg press and chest press muscular endurance was determined as the maximum number of repetitions that could be performed for one set using $80 \%$ baseline 1 -RM for the leg press and $70 \%$ baseline 1-RM for the chest press. The different percentages of 1-RM used for the muscular endurance tests reflect observations that for a given percentage of 1-RM, more repetitions can be performed during lower-body exercises than during upper-body exercises (Chilibeck, Calder, \& Webber, 1998).

Muscle strength and endurance were assessed in order: (a) leg-press strength, (b) chest-press strength, (c) leg-press endurance, (d) chest-press endurance. Five minutes of rest 
separated each test. Muscle strength and endurance determination was separated by 10 minutes of rest.

\section{Functionality}

Dynamic balance was measured as the time taken to perform backwards tandem walking (i.e., toe to heel) over a distance of $6 \mathrm{~m}$ on a $10 \mathrm{~cm}$ wide board that was raised about $4 \mathrm{~cm}$ off the ground. The number of errors (i.e., number of times the participant stepped off the walking board) during the test was recorded. This test has previously been used to assess the effectiveness of exercise training on balance in aging adults (Chilibeck et al., 2013; Nelson, 1994). Walking speed was assessed by the time needed to walk an $80 \mathrm{~m}$ course at a fast pace.

\section{Statistical Analyses}

A $3(\mathrm{CR}-\mathrm{H}$ vs. CR-L vs. PLA) $\times 2$ (pre- and post-test periods) analysis of variance (ANOVA) with repeated measures on the second factor was used to determine differences between groups over time for muscle strength, endurance and tasks of functionality. A onefactor ANOVA was used to determine whether there were differences in baseline measurements between groups All results were expressed as means \pm standard deviation. The magnitude of the difference between significant means was determined by eta squared $\left(\eta^{2}\right)$. This is a measure of the effect size and therefore of the proportion of the total variance that can be explained by the effects of the treatment. A $\eta^{2}$ value of 0.15 represents large differences, 0.06 represents medium differences, and 0.01 represents small differences. Statistical analyses were performed using SPSS version 21.0 for Windows XP (SPSS Chicago, IL). Significance was set at $\mathrm{p}<0.05$. 


\section{Results}

\section{Participants}

Of the original 33 participants who were enrolled, 31 (17 females, 14 males; $58.5 \pm 4.7$ years) completed the study (Table 1). Two male participants in the CR-L group withdrew because of adverse events linked to the supplement. An adverse event form was completed which included one participant reporting diarrhea and resurgence of gout symptoms and the other participant reporting abdominal pain, diarrhea, elevated blood sugars and elevated heart rate) (Appendix D). Other minor adverse events reported however not severe enough to withdraw from the study included a chest cold by two participants (CR-L: $n=1$ female and PLA: $\mathrm{n}=1$ female), two participants reported knee pain (PLA: $n=1$ female, PLA: $n=1$ female), one participant reported a pulled groin muscle (CR-L: n=1 male), one participant reported gastrointestinal symptoms such as gas (CR-L: $\mathrm{n}=1$ male), one participant reported constipation (CR-H: $n=1$ female), one participant reported bloating and feeling full (CR-H: $n=1$ male), and one participant reported muscle cramps (CR-H: $n=1$ male). One female participant in the CR-H group was unable to complete the leg press exercises due to poor hip flexion. During posttesting, participants were asked to guess whether they were taking creatine or placebo. Fifteen participants thought they were taking placebo, 8 thought they were taking creatine and 10 did not know. Only one participant correctly guessed they were taking creatine and five participants correctly guessed they were taking placebo. Changes in all measurements over time were similar between males and females indicating that there were no significant differences amongst gender (Table 1). 
Table 1. Participant Characteristics and supplement dosage for CR-H, CR-L, PLA groups at baseline

\begin{tabular}{|c|c|c|c|}
\hline & CR-H & CR-L & PLA \\
\hline Participants & $\mathrm{n}=11$ & $\mathrm{n}=9$ & $\mathrm{n}=11$ \\
\hline $\begin{array}{c}\text { Gender } \\
\text { (Male/Female) }\end{array}$ & $M=6 F=5$ & $M=3 F=6$ & $M=5 F=6$ \\
\hline $\begin{array}{c}\text { Dosage } \\
\text { (10 consecutive days) }\end{array}$ & $\begin{array}{c}0.3 \mathrm{~g} / \mathrm{kg} / \text { day creatine } \\
+0.1 \mathrm{~g} / \mathrm{kg} / \text { day } \\
\text { maltodextrin }\end{array}$ & $\begin{array}{c}0.1 \mathrm{~g} / \mathrm{kg} / \text { day creatine } \\
+0.3 \mathrm{~g} / \mathrm{kg} / \text { day } \\
\text { maltodextrin) }\end{array}$ & $\begin{array}{l}0.4 \mathrm{~g} / \mathrm{kg} / \mathrm{day} \\
\text { maltodextrin }\end{array}$ \\
\hline Age (yrs) & $59.3 \pm 3.2 \mathrm{yrs}$ & $58.8 \pm 5.9$ & $57.3 \pm 4.6 \mathrm{yrs}$ \\
\hline Height $(\mathrm{cm})$ & $170.8 \pm 8.7 \mathrm{~cm}$ & $170.9 \pm 10.5 \mathrm{~cm}$ & $170.9 \pm 11.3 \mathrm{~cm}$ \\
\hline Weight $(\mathrm{kg})$ & $82.6 \pm 16.8 \mathrm{~kg}$ & $82.3 \pm 16.1 \mathrm{~kg}$ & $84.1 \pm 11.4 \mathrm{~kg}$ \\
\hline $\operatorname{BMI}\left(\mathrm{kg} / \mathrm{m}^{2}\right)$ & 28.3 & 28.2 & 28.8 \\
\hline
\end{tabular}

Values are means \pm standard deviation.

\section{Muscle Strength, Endurance and Functionality}

There was a significant increase over time for leg press strength $(F[1,29]=16.131, p=$ $\left.0.000, \eta^{2}=0.357\right)$, chest press strength $\left(F[1,30]=13.360, p=0.001, \eta^{2}=0.308\right)$, leg press endurance $\left(F[1,29]=15.271, p=0.001, \eta^{2}=0.345\right)$ and chest press endurance $(F[1,29]=$ $12.609, p=0.001, \eta^{2}=0.303$ ), with no differences between groups (Table 2). 
Table 2. Muscle strength (1-RM) and endurance (repetitions to volitional fatigue with 80\% 1-RM for leg press and 70\% baseline 1-RM for chest press) at baseline and after 10 days of supplementation

\begin{tabular}{|c|c|c|c|c|c|c|c|c|c|}
\hline & & $\begin{array}{c}\text { CR-H } \\
(\mathrm{n}=11 \text { chest press }) \\
(\mathrm{n}=10 \text { leg press })\end{array}$ & & & CR-L (n=9) & & & $\operatorname{PLA}(\mathrm{n}=11)$ & \\
\hline $\begin{array}{l}\text { Muscle } \\
\text { Group }\end{array}$ & Pre & Post & $\%$ & Pre & Post & $\%$ & Pre & Post & $\%$ \\
\hline $\begin{array}{l}\text { Chest } \\
\text { Press } \\
\text { Strength }\end{array}$ & $57.0 \pm 26.3$ & $58.8 \pm 28.0^{*}$ & 3.2 & $54.5 \pm 28$ & $56.8 \pm 30^{*}$ & 4.2 & $55.2 \pm 27$ & $58.5 \pm 30^{*}$ & 6.0 \\
\hline $\begin{array}{l}\text { Chest } \\
\text { Press } \\
\text { Endurance }\end{array}$ & $15.6 \pm 2.8$ & $18.9 \pm 2.7^{*}$ & 21.1 & $18.0 \pm 5.0$ & $19.9 \pm 7.1 *$ & 10.6 & $20.5 \pm 6.3$ & $21.6 \pm 5.5^{*}$ & 5.4 \\
\hline $\begin{array}{l}\text { Leg Press } \\
\text { Strength }\end{array}$ & $161.6 \pm 55.2 *$ & $169.2 \pm 59.2 *$ & 4.7 & $145.2 \pm 47.8$ & $151.7 \pm 45^{*}$ & 4.5 & $163.7 \pm 51.5$ & $178.2 \pm 65.6^{*}$ & 8.9 \\
\hline $\begin{array}{l}\text { Leg Press } \\
\text { Endurance }\end{array}$ & $17.1 \pm 6.1$ & $21.0 \pm 7.2^{*}$ & 22.8 & $24.2 \pm 11.6$ & $29.1 \pm 17^{*}$ & 20 & $23.8 \pm 9.7$ & $29.5 \pm 11.9 *$ & 23.9 \\
\hline
\end{tabular}

Values are mean $(\mathrm{kg}) \pm$ standard deviation. $\%=$ percent change over time

*Significantly different post training $(\mathrm{p}<0.05)$. 
There were no changes between groups over time for right hand-grip strength $(\mathrm{F}[1,30]=$ $\left.0.328, p=0.571, \eta^{2}=0.011\right)$, left hand-grip strength $\left(F[1,30]=0.773, p=0.386, \eta^{2}=0.025\right.$;

Table 3), walking speed $\left(F[1,30]=1.525, p=0.226, \eta^{2}=0.048\right)$ and falls $(F[1,30]=0.688, p$ $=0.414, \eta^{2}=0.022 ;$ Table 4$)$. 
Table 3. Hand-grip strength $(\mathrm{kg})$ at baseline and after 10 days of supplementation

$\begin{array}{ccc}\mathrm{Cr}-\mathrm{H} & \mathrm{Cr}-\mathrm{L} & \text { PLA } \\ (\mathrm{n}=11) & (\mathrm{n}=9) & (\mathrm{n}=11)\end{array}$

\begin{tabular}{|c|c|c|c|c|c|c|c|c|c|}
\hline $\begin{array}{l}\text { Hand Grip } \\
\text { Strength }\end{array}$ & Pre & Post & $\%$ & Pre & Post & $\%$ & Pre & Post & $\%$ \\
\hline Left (L) & $34.5 \pm 12.7$ & $34.8 \pm 12.5$ & 0.9 & $37.8 \pm 21.7$ & $38.4 \pm 18.1$ & 1.6 & $30.5 \pm 12$ & $32.4 \pm 12.4$ & 6.2 \\
\hline Right (R) & $34.8 \pm 12.6$ & $35.5 \pm 13.3$ & 2.0 & $41.7 \pm 22.8$ & $40.1 \pm 19.4$ & -3.8 & $32.5 \pm 11.8$ & $35.1 \pm 12.5$ & 8.0 \\
\hline
\end{tabular}

Values are mean $(\mathrm{kg}) \pm$ standard deviation. $\%=$ percent change over time

*Significantly different post training $(\mathrm{p}<0.05)$. 
Table 4. Walking speed (seconds) and number of falls at baseline and after 10 days of supplementation

\begin{tabular}{|c|c|c|c|c|c|c|c|c|c|}
\hline & & $\begin{array}{l}\text { CR-H } \\
(n=10)\end{array}$ & & & $\begin{array}{l}\text { Cr-L } \\
(n=9)\end{array}$ & & & $\begin{array}{c}\text { PLA } \\
(\mathrm{n}=11)\end{array}$ & \\
\hline & Pre & Post & $\%$ & Pre & Post & $\%$ & Pre & Post & $\%$ \\
\hline Balance & $1.5 \pm 1.4$ & $1.1 \pm 1.1$ & -27 & $.91 \pm 1.3$ & $.95 \pm 1.1$ & 4.4 & $1.6 \pm 1.9$ & $2.5 \pm 3.0$ & 56.3 \\
\hline Speed & $38.6 \pm 21.7$ & $38.4 \pm 26.7$ & -0.5 & $39.4 \pm 21.7$ & $36.1 \pm 27.2$ & -8.4 & $36.2 \pm 11.6$ & $33.4 \pm 10.8$ & -7.7 \\
\hline
\end{tabular}

Values are means \pm standard deviation. $\%=$ percent change over time 


\section{Discussion}

This is the first study to directly compare the effects of high-dosage creatine to lowdosage creatine in healthy aging adults. It was hypothesized that high-dosage creatine would increase muscle performance and functionality compared to low-dosage creatine and that creatine intake, independent of dosage, would be superior to placebo. However, creatine had no effect on muscle strength, endurance or tasks of functionality. These results support the previous findings of Baker, Candow, \& Farthing, (2016) who found no effect from acute (bolus) creatine ingestion (20 g) on muscle endurance in healthy aging males. Furthermore, Lobo et al. (2015) found no effect from very-low dosage creatine ( $1 \mathrm{~g} /$ day for 1 year) on properties of muscle, bone or functionality in aging postmenopausal women. A common methodological feature of the present study and that of Baker et al. (2016) and Lobo et al. (2015) was that creatine was consumed independent of resistance training. Therefore, creatine may have to be combined with resistance training to produce significant muscle health benefits in aging adults.

Two meta-analyses have established that the combination of creatine and resistance training increases muscle strength and functionality in aging adults compared to resistance training or creatine alone (Candow et al., 2014; Devries and Phillips, 2014). Devries and Phillips (2014) analyzed over 300 men and women (55-71 years of age) who consumed creatine (3-25 g) during resistance training (7-26 weeks). Compared to placebo, creatine significantly increased upper- and lower-body muscle strength and some tasks of functional performance. In the second meta analyses, Candow et al. (2014) showed that creatine supplementation $(\sim 0.1-0.3 \mathrm{~g} / \mathrm{kg}>6$ weeks) and resistance training in over 300 aging adults increased upper body strength compared to placebo and resistance training. Based on these meta-analyses, it appears that creatine can augment the physiological gains from resistance training. Mechanistically, the greater increase in 
muscle strength and functionality from creatine may be related to its effect on high-energy phosphate metabolism, cellular hydration status, muscle protein kinetics, myogenic transcription factors, satellite cells, anabolic growth factors (i.e. IGF-1) and inflammation (for reviews see Candow 2011; Candow and Chilibeck, 2008; Candow et al., 2014; 2012; Gualano, Rawson, Candow, \& Chilibeck, 2016; Kreider et al., 2017).

Only a few studies have shown beneficial effects from creatine supplementation, independent of resistance training, in aging adults. For example, Stout et al. (2007) showed that 14 days of creatine supplementation ( $20 \mathrm{~g} /$ day for 7 days followed by $10 \mathrm{~g} /$ day for 7 days; $210 \mathrm{~g}$ in total) increased handgrip strength and physical working capacity in elderly men and women (67-82 year of age) with no change for the placebo group. Furthermore, Rawson, Wehnert, \& Clarkson, 1999) showed that 30 days of creatine supplementation (20 g for 10 days followed by $4 \mathrm{~g}$ for 20 days; $280 \mathrm{~g}$ in total) in aging males (60-82 years of age) reduced lower-body muscle fatigue (an indicator of muscle endurance) but had no effect on muscle strength. Other studies have shown that shorter duration ( 7 days) creatine supplementation $(0.3 \mathrm{~g} / \mathrm{kg})$ improved upper and lower body dynamic strength and functionality in aging adults (Gotshalk et al, 2002 \& 2008). While it is difficult to compare results across studies, these inconsistent findings may be partially explained by differences in sample size, supplementation regimens (i.e. dosage and frequency), inclusion of resistance training, study duration, and methods used to assess aging muscle performance and functionality.

\section{Limitations and Strengths}

There were several limitations to this study. Perhaps the biggest limitation involved creatine supplementation without resistance training. Based on the meta-analyses of Candow et al. (2014) and Devries \& Phillips, (2014) creatine may have to be combined with resistance 
training to produce significant gains in muscle strength and functionality in aging adults. Without the inclusion of resistance training, the effects of creatine (low- or high-dosage) may have been insufficient to produce significant effects. Secondly, the inclusion of both males and females may have influenced the results. Females may have higher resting intramuscular creatine levels than males (Forsberg et al., 1991) and therefore may not respond as well to creatine supplementation (Tarnopolsky, 2000). Creatine also appears to have no effect on muscle protein kinetics in females (Parise et al., 2001). Third, the estimated sample size required to achieve $80 \%$ power was 42 subjects. Unfortunately, only 33 participants completed the study which likely decreased statistical power. Fourth, participant motivation and the performance of activities of daily living may have affected the pre- and post-study measurements. In addition, the familiarization period may not have been long enough in duration to decrease neuromuscular learning. For example, it has been shown that multiple familiarization sessions help produce reliable strength results in older adults (Phillips, Batterham, Valenzuela, \& Burkett, 2004). Fifth, no measure of habitual dietary intake was performed. Creatine is naturally found in red meat and seafood and consumption of these food products may have influenced the results. Sixth, muscle biopsies were not performed which eliminates the ability to assess responders and non-responders to creatine supplementation. The ergogenic effects of creatine may depend on the initial muscle creatine concentration, which varies with age and between genders (Dalbo et al., 2009; Syrotuik \& Bell, 2004 ). Finally, muscle cross-sectional area, myogenic transcription factors, muscle protein kinetics, hormonal properties and satellite cell number and activity were not measured.

The strengths of the study were that the samples selected were closely representative of the aging population being studied. Therefore, findings could be applied to the general public 
to guide the use of creatine supplementation to achieve optimal benefits. These included first, creatine supplementation should be combined with resistance training and second a higher dose is not more effective than a lower dose.

\section{Conclusions}

The age-related loss of muscle strength and endurance decreases our ability to perform activities of daily living (Short \& Nair, 2001). One potential intervention that may benefit aging muscle is creatine supplementation. While creatine supplementation may have beneficial effects on aging muscle performance, the optimal dosage needed to attain these benefits is unclear.

This was the first study to directly compared low vs. high-dose creatine in aging adults. Results showed no effect from creatine (low or high-dosage) on muscle strength, endurance or tasks of functionality. The implications of this study are important for direction on the use of creatine in research and development of creatine supplementation protocols to improve aging muscle health. Future research is needed to determine the long-term effects of different creatine dosing strategies, when combined with resistance training, on properties of muscle and bone health in aging adults. 


\section{References}

Adhihetty, P. J., \& Beal, M. F. (2008). Creatine and its potential therapeutic value for targeting cellular energy impairment in neurodegenerative diseases. Neuromolecular Medicine, 10(4), 275-290.

Agaard, P., Suetta, C., Caserotti, P., Magnusson, S. P., \& Kjaer, M. (2010). Role of the nervous system in sarcopenia and muscle atrophy with aging: Strength training as a countermeasure. Scandinavian Journal of Medicine and Science in Sports, 20, 49-64.

Andrews, R. D., MacLean, D. A., \& Riechman, S. E. (2006). Protein intake for skeletal muscle hypertrophy with resistance training in seniors. International Journal of Sport Nutrition and Exercise Metabolism, 16, 362-372.

Ansved, T., \& Larsson, L. (1989). Effects of ageing on enzyme-histochemical, morphometrical, and contractile properties of the soleus muscle in the rat. Journal of Neurological Science, 93,1, 105-124.

Ansved, T., \& Edstrom, L. (1991). Effects of age on fibre structure, ultrastructure and expression of desmin and spectrin in fast and slow-twitch rat muscles. Journal of Anatomy, 174, 6169.

Atherton, P. J., Smith, K., Etheridge, T., \& Rankin, D. (2010). Distinct anabolic signalling responses to amino acids in $\mathrm{C} 2 \mathrm{C} 12$ skeletal muscle cells. Amino Acids, 38(5), 1533 1539.

Baker, T.P., Candow, D.G. \& Farthing, J.P. (2016). Effect of preexercise creatine ingestion on muscle performance in healthy aging males. Journal of Strength Conditioning and Research, 30 (6), 1763-6. 
Balagopal, P., Schimke, J.C., Ades, P., Adey, D., \& Nair, K.S. (2001). Age effect on transcript levels and synthesis rate of muscle $\mathrm{MHC}$ and response to resistance exercise. The American Journal of Physiology - Endocrinology metabolism, 280, 2, E203-208.

Bales, C. W., \& Ritchie, C. S. (2002). Sarcopenia, weight loss and nutritional frailty in the elderly. Annual Review of Nutrition, 22, 309-323.

Balsom, P. D., Soderlund, K., \& Ekblom, B. (1994). Creatine in humans with special reference to creatine supplementation. Sports Medicine, 18, 268-280.

Balsom, P. D., Söderlund, K., Sjödln, B., \& Ekblom, B. (1995). Skeletal muscle metabolism during short duration high-intensity exercise: influence of creatine supplementation. Acta Physiologica- The Scandanavian Physiological Society, 154, 3, 303-10.

Barazzoni, R., Short, K. R., \& Nair, K. S. (2000). Effects of aging on mitochondrial DNA copy number and cytochrome c oxidase gene expression in rat skeletal muscle, liver, and heart. Journal of Bioogical Chemistry, 275, 3343-3347.

Baumgartner, R.N., Waters, D.L., Gallagher, D., Morley, J.E., Garry, P.J. (1999) Predictors of skeletal muscle mass in elderly men and women. Mechanisms of Ageing and Development, 107:123-36.

Bazzucchi, I., Felici, F., \& Sacchetti, M. (2009). Effect of short-term creatine supplementation on neuromuscular function. Medicine \& Science in Sports and Exercise, 41(10), 1934-41.

Bea, J. W., Cussler, E. C., Going, S. B., Blew, R. M., Metcalfe, L. L., \& Lohman, T. G. (2009). Resistance training predicts six-year body composition change in postmenopausal women. Medicine \& Science in Sports \& Exercise, 42(7), 1286-1295. 
Berneis, K., Ninnis, R., Haussinger, D., \& Keller U (1999). Effects of hyper- and hypoosmolality on whole body protein and glucose kinetics in humans. American Journal of Physiology, 276, E188-195.

Bessman, S., \& Savabi, F. (1988). The role of phosphocreatine energy shuttle in exercise and muscle hypertrophy. In M. A. Conway \& J. F. Clark (Eds.), Creatine and creatine phosphate: Scientific and clinical perspectives (pp. 185-198). San Diego, CA: Academic Press.

Bloch, K., \& Schoenheimer, R. (1941). The biological precursors of creatine. The Journal of Biological Chemistry, 138(1), 167-194.

Brack, A. S., \& Rando, T. A. (2007). Intrinsic changes and extrinsic influences of myogenic stem cell function during aging. Stem Cell Reviews and Reports, 3, 226-237.

Breen, L., \& Phillips, S. M. (2011). Skeletal muscle protein metabolism in the elderly: Interventions to counteract the anabolic resistance of ageing. Nutrition and Metabolism, $8,68$.

Brody, I. A. (1976). Regulation of isometric contraction in skeletal muscle. Experimental Neurology, 50(3), 673-683.

Brose, A., Parise, G., \& Tarnopolsky, M. A. (2003). Creatine supplementation enhances isometric strength and body composition improvements following strength exercise training in older adults. The Journals of Gerontology. Series, Biological Sciences and Medical Sciences, 58, 11-19.

Brunzel, N. A. (2003). Renal function: Nonprotein nitrogen compounds, function tests, and renal disease. In J. Scardiglia, M. Brown, K. McCullough, \& K. Davis (Eds.), Clinical chemistry (pp. 373-399). New York, NY: McGraw-Hill. 
Buford, T. W., Anton, S. D., Judge, A. R., Marzetti, E., Wohlgemuth, S. E., Carter, C. S., . . Manini, T. M. (2010). Models of accelerated sarcopenia: Critical pieces for solving the puzzle of age-related muscle atrophy. Ageing Research Reviews, 9(4), 369-383.

Burke, D. G., Candow, D. G., Chilibeck, P. D., MacNeil, L. G., Roy, B. D., Tarnopolsky, M. A., \& Ziegenfuss, T. (2008). Effect of creatine supplementation and resistance-exercise training on muscle insulin-like growth factor in young adults. International Journal of Sport Nutrition and Exercise Metabolism, 18(4), 389-398.

Burke, D. G., Chilibeck, P. D., Parise, G. A., \& Author, A. (2001). The effect of alpha lipoic acid supplementation on resting muscle creatine during acute creatine loading. The Faseb Journal, 15(5), A814.

Butterfield, G.E., Thompson, J., Rennie, M.J., Marcus, R., Hintz, R.L., \& Hoffman, A.R. (1997) Effect of rhGH and rhIGF-I treatment on protein utilization in elderly women. American Journal of Physiololgy, 272: E94-E99.

Campbell, W. W. (2007). Synergistic use of higher-protein diets or nutritional supplements with resistance training to counter sarcopenia. Nutrition Reviews, 65, 416-422.

Campbell, W. W., \& Evans, W. J. (1996). Protein requirements of elderly people. European Journal of Clinical Nutrition, 50 (suppl 1), S180-S183, S183-S185.

Campbell, W. W., Trappe, T. A., Wolfe, R. R., \& Evans, W. J. (2001). The recommended dietary allowance for protein may not be adequate for older people to maintain skeletal muscle. The Journals of Gerontology: Series A, Biological Sciences and Medical Sciences, 56, M373-380. 
Candow, D. G., \& Chilibeck, P. D. (2008). Timing of creatine or protein supplementation and resistance training in the elderly. Applied Physiology Nutrition Metabolism, 33(1), 184190.

Candow, D. G., Little, J. P., Chilibeck, P. D., Abeysekara, S., Zello, G. A., Kazachkov, M. . . Yu, P. H. (2008). Low-dose creatine combined with protein during resistance training in older men. Medicine and Science in Sports and Exercise, 40(9), 1645-1652.

Candow, D. G., Chilibeck, P. D., Burke, D. G., Mueller, K. D., \& Lewis, J. D. (2011). Effect of different frequencies of creatine supplementation on muscle size and strength in young adults. The Journal of Strength \& Conditioning Research, 25(7), 1831-1838.

Candow, D. G., Forbes, S. C., Little, J. P., Cornish, S. M., Pinkowski, C., \& Chilibeck, P. D. (2012). Effect of nutritional interventions and resistance exercise on aging muscle mass and strength. Biogerontology, 13, 345-358.

Candow, D. G., Chilibeck, P. D., \& Forbes, S. C. (2014). Creatine supplementation and aging musculoskeletal health. Endocrine, 45(3), 354-361.

Candow, D. G., Vogt, E., Johannsmeyer, S., Forbes, S. C., \& Farthing, J. P. (2015). Strategic ingestion of creatine supplementation and resistance training in healthy older adults. Applied Physiology Nutrition and Metabolism, 40 (7), 689-94.

Canete, S., San Juan, A.F., Perez, M., Gomez-Gallego, F., Lopez-Mojares, L.M., Earnest C.P., ....Lucia, A. (2006). Does creatine supplementation improve functional capacity in elderly women. Journal of Strength and Conditioning Research, 20(1), 22-8.

Casey, A., Constantin-Teodosiu, D., Howell, S., Hultman., E., Greenhaff. (1996). Creatine ingestion favorably effects performance and muscle metabolism during maximal exercise in humans. American journal of physiology, 27(1), 31-37. 
Chakravarthy, M. V., Spangenburg, E. E., \& Booth, F. W. (2001). Culture in low levels of oxygen enhances in vitro proliferation potential of satellite cells from old skeletal muscles. Cellular and Molecular Life Sciences, 58(8), 1150-1158.

Chilibeck, P. D., Calder, A. W., Sale, D. G., \& Webber, C. E. (1998). A comparison of strength and muscle mass increases during resistance training in young women. European Journal of Applied Physiology and Occupational Physiology, 77(1-2), 170-175.

Chilibeck, P. D., Vatanparast, H., Pierson, R., Case, A., Olatunbosun, O., Whiting, S. J., . . Biem, H. J. (2013). Effect of exercise training combined with isoflavone supplementation on bone and lipids in postmenopausal women: A randomized clinical trial. Journal of Bone and Mineral Research, 28(4), 780-793.

Chilibeck, P., Candow, D., Landeryou, T., Kaviani, M., Paus-Jenssen, L. (2015). Effects of creatine and resistance trinaing on bone health in post-menopausal women. Medicine and Science in Sports and Exercise, 47(8), 1587-1595.

Chilibeck, P.D., Paterson, D.H, McCreary, C.R., Marsh, G.D., Cunningham, D.A., \& Thompson, R.T. (1998). The effects of age on kinetics of oxygen uptake and phosphocreatine in humans during exercise. Experimental Physiology, 83(1):107-17.

Christie, D. L. (2007). Functional insights into the creatine transporter. In Gajja S. Salomons, M. Wyss (Eds.), Creatine and creatine kinase in health and disease (pp. 99-118). Netherlands: Springer.

Coggan, A. R., Spina, R. J., Rogers, M. A., King, D.D., Brown, M., Nemeth, P.M., \& Holloszy, J.O. (1990). Histochemical and enzymatic characteristics of skeletal muscle in master athletes. Journal of Applied Physiology, 68, 1896-1901. 
Combaret, L., Dardevet, D., Bechet, D., Taillandier, D., Mosoni, L., Attaix, D. (2009). Skeltal muscle proteolysis in aging. Current opinion in Clinical Nutrition and Metabolic care, 12 (1), 37-41.

Cook, M. B., Brabham, B., Buford, T. W., Shelmadine, B. D., McPheeters, M. M., Hudson, G. M., .. . Willoughby, D. S. (2014). Creatine supplementation post-exercise does not enhance training-induced adaptations in middle to older aged males. European Journal of Applied Physiology, 114, 1321-1332.

Cramer, J. T. (2008). Creatine supplementation in endurance sports. In J. R. Strout, J. Antonio, \& D. Kalman (Eds.), Essentials of creatine in sports and health (pp. 45-99). Totwa, NJ: Humana Press.

Dalbo, V. J., Roberts, M. D., Lockwood, C. M., Tucker, P. S., Kreider, R. B., \& Kerksick, C. M. (2009). The effects of age on skeletal muscle and the phosphocreatine energy system: can creatine supplementation help older adults. Dynamic Medicine, 8(1), 6.

Dangott, B., Schultz, E., Mozdziak, P.E. (2000). Dietary creatine monohydrate supplementation increases sattelite cell mitotic activity during compensitory hypertrophy. International journal of sports medicine, 21(1), 13-6.

Decoster, W., Reuck, J., Sieben, G., \& Eecken, H. V. (1981). Early ultrasound changes in aging rat gastrocnemius muscle: A stereologic study. Muscle \& Nerve, 4(2), 111-116.

Deldicque, L., Louis, M., Theisen, D., Nielens, H., Dehoux, M., Thissen, J.-P., . . Francaux, M. (2005). Increased IGF mRNA in human skeletal muscle after creatine supplementation. Medicine \& Science in Sports \& Exercise, 37(5), 731-736.

Deminice, R., \& Jordao, A. A. (2011). Creatine supplementation reduces oxidative stress biomarkers after acute exercise in rats. Amino Acids, 43(2), 709-715. 
Deschenes, M. R. (2004). Effects of aging on muscle fibre type and size. Sports Medicine, 34, 809-824.

Devries, M. C., \& Phillips, S. M. (2014). Creatine supplementation during resistance training in older adults-A meta-analysis. Medicine and Science in Sports and Exercise, 46, 1194 1203.

Dionne, I. J., Kinaman, K. A., \& Poehlman, E. T. (2000). Sarcopenia and muscle function during menopause and hormone-replacement therapy. Journal of Nutrition in Health and Aging, 4, 156-161.

Doherty, T. J. (2003). Invited review: Aging and sarcopenia. Journal of Applied Physiology, 95(4), 1717-1727.

Evans, W. J. (1995). Effects of exercise on body composition and functional capacity of the elderly. The Journals of Gerontology. Series A, Biological Sciences and Medical Sciences, 50, 147-150.

Evans, W. J. (1995). What is sarcopenia? The Journals of Gerontology. Series A, Biological Sciences and Medical Sciences, 50, 5-8.

Faul, F., Erdfelder, E., Lang, A.-G., \& Buchner, A. (2007). G*Power 3: A flexible statistical power analysis program for the social, behavioral, and biomedical sciences. Behavior Research Methods, 39(2), 175-191.

Fiske, C.H, \& Subbarow, Y. (1927). The nature of the "inorganic phosphate" in voluntary muscle. Science. 65 (1686):401-403.

Finn, J. P., Ebert, T. R., Withers, R. T., Carey, M. F., Mackay, M., Phillips, J. W., \& Febbraio, M. A. (2001). Effect of creatine supplementation on metabolism and performance in 
humans during intermittent sprint cycling. European Journal of Applied Physiology, 84, $238-243$.

Forsberg, A. M., Nilsson, E., Werneman, J., Bergström, J., \& Hultman, E. (1991). Muscle composition in relation to age and sex. Clinical Science, 81(2), 249-256.

Gopinath, S. D., \& Rando, T. A. (2008). Stem cell review series: Aging of the skeletal muscle cell niche. Aging Cell, 7(4), 590-598.

Gotshalk, L. A., Volek, J. S., Staron, R. S., Denegar, C. R., Hagerman, F. C., \& Kraemer, W. J. (2002). Creatine supplementation improves muscular performance in older men. Medicine and Science in Sports and Exercise, 34, 537-543.

Gotshalk, L. A., Kraemer, W. J., Mendonca, M. A., Vingren, J. L., Kenny, A. M., Spiering, B. A., ... Volek, J. S. (2008). Creatine supplementation improves muscular performance in older women. European Journal of Applied Physiology, 102, 223-231.

Greenhaff, P.D., K. Bodin, K. Soderland, and Hultman,E. (1994). Effect of oral creatine supplementation on skeletal muscle phosphocreatine resynthesis. American Journal of Physiology, 266: 725- 730.

Greenhaff, P. (1997). The nutritional biochemistry of creatine. The Journal of Nutrition Biochemistry, 11, 610-618.

Gualano, B., Rawson, E.S., Candow, D.G., Chilibeck, P.D. (2016). Creatine supplementation in the aging population: effects on skeletal muscle bone and brain. Amino Acids, 48(8), 1793-805.

Harris, R.C., Soderlund., K., \& Hultman, E. (1992). Elevation of creatine in resting and exercised muscle of normal subjects by creatine supplementation. Clinical Science, 82(3), $367-74$. 
Häussinger D (1996): The role of cell hydration for the regulation of cell function. Biochemistry. Journal, 313, 697-710.

Hawke, T.J., \& Gary D.J. (2001). Myogenic satellite cells: physiology to molecular biology. Journal of Applied Physiology, 91(2), 534-51.

Henriksson, J., \& Sahlin, K. (2003). Metabolism during exercise-energy expenditure and hormonal changes. In M. Kjaer, M. Krogsgaard, P. Magnusson, L. Engebretsen, H. Roos, T. Takala, \& S. L.-Y. Woo (Eds.), Textbook of sports medicine: Basic science and clinical aspects of sports injury and physical activity (pp. 30-48). Malden, MA: Blackwell Science Ltd.

Hepple, R.T. (2003). Sarcopenia, a critical perspective. Science of Aging Knowledge Environment, 46, 31.

Hepple, R.T. (2014). Mitochondrial involvement and impact in aging skeletal muscle. Front Aging Neuroscience, 6, 211.

Herndon, L. A., Schmeissner, P. J., Dudaronek, J. M., Brown, P.A., Listner, K.M., Sakano, Y.......Driscoll, M. (2002). Stochastic and genetic factors influence tissue-specific decline in ageing C. elegans. Nature, 419, 808-814.

Hespel, P., Op’t Eijnde, B., Van Leemputte, M., Urso, B., PL., Greenhaff., Labarque, V., Dymarkowski, S., Van Hecke, P., \& Richter, E.A. (2001). Oral creatine supplementation f acilitates the rehabilitation of disuse atrophy and alters the expression of muscle myogenic factors in humans. Journal of Physiology 536: 625-633.

Heymsfield, S. B., Arteaga, C., McManus, C., Smith, J., \& Moffitt, S. (1983). Measurement of muscle mass in humans: Validity of the 24-hour urinary creatine method. American Journal of Clinical Nutrition, 37, 478-494. 
Hultman, E., Bergstrom, J., Spreit, L., \& Soderlund, K. (1990). Energy metabolism and fatigue. In A. Taylor, P. D. Gollnick, \& H. Green (Eds.), Biochemistry of exercise (Vol. VII, pp. 73-92). Champaign, IL: Human Kinetics.

Hunter, G., McCarthy, J., \& Bamman, M. (2004). Effects of resistance training on older adults. Sports Medicine, 34(5), 329-348.

Iglay, H. B., Thyfault, J. P., Apolzan, J. W., \& Campbell, W. W. (2007). Resistance training and dietary protein: Effects on glucose tolerance and contents of skeletal muscle insulin signaling proteins in older persons. American Journal of Clinical Nutrition, 85, 10051013.

Ingwall, J.S. (1976). Creatine and the control of muscle-specific protein synthesis in cardiac and skeletal muscle. Circulation Research 38: 115-123.

Jejurikar, S. S., Henkelman, E. A., Cederna, P. S., Marcelo, C. L., Urbanchek, M. G., \& Kuzon, W. M. (2006). Aging increases the susceptibility of skeletal muscle derived satellite cells to apoptosis. Experimental Gerontology, 41(9), 828-836.

Johnston, A. P. W., De Lisio, M., \& Parise, G. (2008). Resistance training, sarcopenia, and the mitochondrial theory of aging. Applied Physiology, Nutrition, and Metabolism, 33(1), $191-$ 199.

Karakelides, H., \& Nair, K. (2005). Sarcopenia of aging and its metabolic impact. Current Topics in Developmental Biology, 68, 123-148.

Kent-Braun JA, Ng AV. (1985). Skeletal muscle oxidative capacity in young and older women and men. Journal of Applied Physiology, 89(3):1072-8. 
Kimball, S. R., \& Jefferson, L. S. (2006). Signaling pathways and molecular mechanisms through which branched-chain amino acids mediate translational control of protein synthesis. Journal of Nutrition, 136(1 Suppl.), 227S-231S.

Kirkwood, T. B., \& Finch, C. E. (2002). Ageing: The old worm turns more slowly. Nature, 419, $794-795$.

Kraemer, W. J., \& Volek, J. S. (1999). Creatine supplementation. Its role in human performance. Clinical Sports Medicine, 18, 651-666.

Kreider, R.B., Ferreira, M., Wilson, M., Grindstaff, P., Plisk, S., Reinardy, J.....\& Almada, A.L. (1998). Effects of creatine supplementation on body composition, strength and sprint performance. Medicine and Science in Sports and Exercise, 30: 73-82.

Kreider, R.B. (2003). Effects of creatine supplementation on performance and training adaptations. Molecular and Cellular Biochemistry, 244, 1-2, 89-94.

Kreider, R.B., Kalman, D.S., Antonio, J., Ziegenfuss, T.N., Wildman, R., Collins, R.... Lopez,H. L. (2017). International Society of Sports Nutrition position stand: safety and efficacy of creatine supplementation in exercise, sport, and medicine. Journal of the International Society of Sports Nutrition. Jun (13), 14-18.

Ladner, K. J., Caligiuri, M. A., \& Guttridge, D. C. (2003). Tumor necrosis factor-regulated biphasic activation of NF-kappa B is required for cytokine-induced loss of skeletal muscle gene products. The Journal of Biological Chemistry, 278(4), 2294-2303.

Lanza, I.R., \& Nair, K.S. (2009). Muscle mitochondrial changes with aging and exercise. The American Journal of Clinical Nutrition, 89, 1, 467S-471S. 
Lasrsson, L. \& Edstrom, L. (1986). Effects of age on enzyme-histochemical fibre spectra and contractile properties of fast and slow-twitch skeletal muscles in the rat. Journal of the Neurological Sciences, 76 (1), 69-89.

Larsson, L., \& Salviati, G. (1989). Effects of age on calcium transport activity of sarcoplasmic reticulum in fast and slow-twitch rat muscle fibres. The Journal of Physiology, 419, 253264.

Larsson, L., Yu, F., Hook, P., Ramamurthy, B., Marx, J. O., \& Pircher, P. (2001). Effects of aging of regulation of muscle contraction. Bio gerontology, 13, 345-358

Lefavi, R. G., Mcmillan, J. L., Kahn, P. J., Crosby, J. F., DiGioacchino, R. F., \& Streater, J. A. (1998). Effects of creatine monohydrate on performance of college baseball and basketball players. The Journal of Strength and Conditioning Research, 12, 275.

Lexell, J. (1995). Human aging, muscle mass, and fiber type composition. The Journals of Gerontology, Series A Biological Sciences and Medical Sciences, 50, 11-16.

Lexell, J. (1997). Evidence for nervous system degeneration with advancing age. Journal of Nutrition, 127, 1011S-1013S.

Lexell, J., Henriksson-Larsen, K., Winblad, B., \& Sjostrom, M. (1983). Distribution of different fiber types in human skeletal muscles: Effects of aging studied in whole muscle cross sections. Muscle Nerve, 6, 588-595.

Lobo, D.M., Tritto, A.C., Da Silva, L.R., De Oliveira, P.B, Benatti, F.B., Roschel, H., Neib, B.........Pereira, R.M. (2015). Effects of long-tern low-dose dietary creatine supplementation inn older women. Experimental Gerontology, 70, 97-104. 
Lowe, M. T., Faull, R. L., Christie, D. L., \& Waldvogel, H.J. (2015). The distribution of the creatine transporter throughout the human brain reveals a spectrum of creatine transporter immunoreactivity. Journal of Comparative Neurology, 523(5), 699-725.

Marcell, T.J. (2003). Sarcopenia: causes, consequences and preventions. Journal of Gerontology, 58(10), 911-16.

Mauro, A. (1961). Satellite cell of skeletal muscle fibers. The Journal of Biophysical and Biochemical Cytology, 9(2), 493-495.

McCully, K.K., Fielding, R.A., Evans, W.J., Leigh, J.S., \& Posner, J.D. (1993). Relationships between invivo and in vitro measurements of metabolism in young and old human calf muscles. Journal of Applied Physiology, 75, 813-819.

McCully, K. K., Forciea, M. A., Hack, L. M., Donlon, E., Wheatley, R. W., Oatis, C. A., . . Chance, B. (1991). Muscle metabolism in older subjects using P magnetic resonance spectroscopy. Canadian Journal of Physiology and Pharmacology, 69, 576-580.

Nair, K. S. (2005). Aging muscle. American Journal of Clinical Nutrition, 81, 953-963.

Nakao, M., Inoue, Y., \& Murakami, H. (1989). Aging process of leg muscle endurance in males and females. European Journal of Applied Physiology and Occupational Physiology, 59 (3), 209-14.

Nelson, M. E. (1994). Effects of high-intensity strength training on multiple risk factors for osteoporotic fractures. Journal of the American Medical Association, 272(24), 19091914.

Olsen, S., Aagaard, P., Kadi, F., Tufekovic, G., Verney, J., Olesen, J......\& Kjaer, M. (2006). Creatine supplementation augments the increase in satellite cell and myonuclei number in 
human skeletal muscle induced by strength training. Journal of Physiology, $572(\mathrm{Pt} 2)$, $525-534$.

Paddon-Jones, D., Short, K. R., Campbell, W. W., Volpi, E., \& Wolfe, R. R. (2008). Role of dietary protein in the sarcopenia of aging. American Journal of Clinical Nutrition, $1562 \mathrm{~S}-1566 \mathrm{~S}$.

Parise, G., Mihic, S., MacLennan, D., Yarasheski, K. E., \& Tarnopolsky, M. A. (2001). Effects of acute creatine monohydrate supplementation on leucine kinetics and mixed-muscle protein synthesis. Journal of Applied Physiology, 91(3), 1041-1047.

Persky, A.M., \& Brazeau, G.A. (2001). Clinical pharmacology of the dietary supplement creatine monohydrate. Pharmacological Review, 53(2):161-76.

Phillips, W.T, Batterham, A.M., Valenzuela, J.F., \& Burkett, L.N. (2004). Reliability of maximal strength testing in older adults. Archives of physical medicine and rehabilitation, 30 (6), $1763-66$.

Proctor, D. N., Balagopal, P., \& Nair, K. S. (1998). Age-related sarcopenia in humans is associated with reduced synthetic rates of specific muscle proteins. Journal of Nutrition, 128(suppl 1), 351S-355S.

Rawson, E. S., Wehnert, M. L., \& Clarkson, P. M. (1999). Effects of 30 days of creatine ingestion in older men. European Journal of Applied Physiology and Occupational Physiology, 80, 139-144.

Rawson, E. S., Clarkson, P. M., Price, T. B., \& Miles, M. P. (2002). Differential response of muscle phosphocreatine to creatine supplementation in young and old subjects. Acta Physiologica Scandinavica, 174, 57-65. 
Rawson, E.S., \& Volek, J.S. (2003). Effects of creatine supplementation and resistance training on muscle strength and weight lifting performance. Journal of Strength Conditioning and Research, 17(4), 822-31.

Rennie, M.J., \& Tipton, K.D. (2000). Protein and amino acid metabolism during and after exercise and the effects of nutrition. Annual Review of Nutrition 20: 457-483.

Rieu, I., Balage, M., Sornet, C., Giraudet, C., Pujos, E., Grizard, J., . . \& \& Dardevet, D. (2006). Leucine supplementation improves muscle protein synthesis in elderly men independently of hyperaminoacidaemia. The Journal of Physiology, 575(1), 305-315

Roberts, S. B. (1995). Effects of aging on energy requirements and the control of food intake in men. The Journals of Gerontology, Series A, Biological Sciences and Medical Sciences, $50,101-106$.

Rooyackers, O. E., Adey, D. B., Ades, P. A., \& Nair, K. S. (1996). Effect of age in vivo rates of mitochondrial protein synthesis in human skeletal muscle. Proceedings of the National Academy of Sciences USA, 93, $15364-15369$.

Rossiter, H. B., Cannell, E. R., \& Jakeman, P. M. (1996). The effect of oral creatine supplementation on the 1000-m performance of competitive rowers. Journal of Sports Sciences, 14(2), 175-179.

Ryall J. G., Schertzer J. D., \& Lynch, G. S. (2008). Cellular and molecular mechanisms underlying age-related skeletal muscle wasting and weakness. Biogerontology 9, 213228.

Safdar, A., Yardley, N. J., Snow, R., Melov, S., \& Tarnopolsky, M. A. (2008). Global and targeted gene expression and protein content in skeletal muscle of young men following 
short term creatine monohydrate supplementation. Physiological Genomics, 32(2), 219228.

Sestili, P., Martinelli, C., Colombo, E., Barbieri, E., \& Potenza, L. (2011). Creatine as an antioxidant. Amino Acids, 40(5), 1358-1396.

Short, K. R., \& Nair, K. S. (2001). Muscle protein metabolism and the sarcopenia of aging. International Journal of Sport Nutrition and Exercise Metabolism, 11, S119-S127.

Short, K. R., Vittone, J., Bigelow, M. L., Proctor, D.N., Rizza, R.A., Coenen-Schimke, J.M., \& Nair, K.S. (2003). Impact of aerobic exercise training on age-related changes in insulin sensitivity and muscle oxidative capacity. Diabetes, 52, 1888-1889.

Siegman, M,J., \& Butler, T.M. (1985). Energetics and regulation of crossbridge states in mammalian smooth muscle. Experientia, 41(8), 1020-1025.

Singh, M. A. F. (2000). Exercise, nutrition and the older woman. Boca Raton, FL: CRC Press.

Smith, S.A., Mountain, S.J., Matott, R.P., Zientara, G.P., Jolesz, F.A., \& Fielding, R.A. (1985). Creatine supplementation and age influence muscle metabolism during exercise. Journal of Applied Physiology, 85(4), 1349-56.

Sohal, R. S., \& Weindruch, R. (1996). Oxidative stress, caloric restriction and aging. Science, 273(5271), 59-63.

Solis, M.Y., Artioli, G.G., Otaduy, M.C.G., Leite, C.D., Arruda, W., Ramos, R.......\& Gualano, B. (2017). Effect of age diet and tissue type on PCr response to creatine supplementation. Journal of Applied Physiology, DOI: 10.1152/japplphysiol.00248.2017

Stout, J., Graves, B., Cramer, J., Goldstein, E., Costa, B., Smith, A., \& Walter, A. (2007). Effects of creatine supplementation on the onset of neuromuscular fatigue threshold and muscle 
strength in elderly men and women (64-86 years). The Journal of Nutrition Health and Aging, 11(6), 459-464.

Strumia, E., Pelliccia, F., D’Ambrosio, G. (2012). Creatine phosphate: pharmological and clinical perspectives. Advances in Therapy, 29(2), 99-123.

Syrotuik, D.G., Bell, G.J. (2004). Acute creatine monohydrate supplementation: a descriptive physiological profile of responders versus non responders. Journal of Strength Conditioning and Research, Aug;18(3):610-7.

Tarnopolsky, M. A. (2000). Gender differences in metabolism; nutrition and supplements. Journal of Science and Medicine in Sport, 3(3), 287-298.

Tarnopolsky, M. A., \& Beal, M. F. (2001). Potential for creatine and other therapies targeting cellular energy dysfunction in neurological disorders. Annals of Neurology, 49(5), 561574.

Thompson, L.V. (2009). Age-related muscle dysfunction. Experimental Gerontology, 44 (1-2), 106-111.

Tipton, K. D. (2001). Muscle protein metabolism in the elderly: Influence of exercise and nutrition. Canadian Journal of Applied Physiology, 26, 588-606.

Trappe, S. (2001). Master athletes. International Journal of Sport Nutrition and Exercise Metabolism, 11: 196-207.

Trappe, T.A., White, F., Lambert, C.P., Cesar, D., Hellerstein, M., Evans, W.J. (2002). Effect of ibuprofen and acetaminophen on post exercise muscle protein synthesis. American Journal of Physiology and Endocrinology metabolism, 282(3), E551-6. 
Verdijk, L. B., Koopman, R., Schaart, G., Meijer, K., Savelberg, H. H., \& Van Loon, L. J. (2007). Satellite cell content is specifically in type II skeletal muscle fibers in the elderly. American Journal of Physiology and Endocrinology Metabolism, 292(1): E151-157.

Viner, R. L., Huhmer, A. F., Bigelow, D. J., \& Schoneich, C. (1996). The oxidative inactivation of sarcoplasmic reticulum (Ca 2+) -ATPase by peroxynitrite. Free Radical Research, 24(4), 243-259.

Volek, J. S., \& Kraemer, W. J. (1996). Creatine supplementation: Its effect on human muscular performance and body composition. Journal of Strength and Conditioning and Research, $10(3), 200-210$.

Volek, J.S., Duncan,N.D., Mazzetti, S.A., Staron, R., Putukian, M., Gomez, A.......\& Kraemer, W.J (1999). Performance and muscle fiber adaptations to creatine supplementation and heavy resistance training. Medicine and Science in Sports and Exercise 312: 1147-1156.

Volek, J. S., Ballard, K. D., \& Forsythe, C. E. (2008). An overview of creatine metabolism. In J. R. Stout, J. Antonio, \& D. Kalman (Eds.), Essentials of creatine in sports and health (pp. 1-23). Totowa, NJ: Humana Press.

Walker, J. B. (1979). Creatine: Biosynthesis, regulation, and function. Advances in Enzymology and Related Areas of Molecular Biology, 50, 177-242.

Wallimann, T., Dolder, M., Schlattner, U., Eder, M., Hornemann, T., O’Gorman, E., Ruck, A., \& Brdiczka, D. (1998). Some new aspects of creatine kinase (CK): Compartmentation, structure, function and regulation for cellular and mitochondrial bioenergetics and physiology. Biofactors, 8, 229-234.

Wallimann, T., Wyss, M., Brdiczka, D., Nicolay, K., \& Eppenberger, H.M. (1992). Intracellular compartmentation, structure and function of creatine kinase isoenzymes in tissues with 
high and fluctuating energy demands: The 'phosphocreatine circuit' for cellular energy homeostasis. Biochemical Journal, 281(Pt 1), 21-40.

Welle, S., Thornton, C., Statt, M., \& McHenry, B. (1996). Growth hormone increases muscle mass and strength but does not rejuvenate myofibrillar protein synthesis in healthy subjects over 60 years old. Journal of Endocrinology and Metabolism, 81(9), 3239-43.

Williams, M. H., \& Branch, J. D. (1998). Creatine supplementation and exercise performance: An update. The Journal of the American College of Nutrition, 17, 216-234.

Williams, M. H., Kreider, R., \& Branch, J. D. (1999). In creatine: The power supplement. Champaign, IL: Human Kinetics Publishers.

Willoughby, D.S., and J.M. Rosene. (2003). Effects of oral creatine and resistance training on 923myogenic regulatory factor expression. Medicine and Science in Sports and Exercise 35, 929.

Wolfe, R. R., Miller, S. L., \& Miller, K. B. (2008). Optimal protein intake in the elderly. Clinical Nutrition, 27(5), 675-684.

Wyss, M., \& Kaddurah-Daouk, R. (2000). Creatine and creatinine metabolism. Physiology Review, 80(3), 1107-1213. 


\section{Appendix A}

Leisure-Time Exercise Questionnaire

Name:

Date:

- Please do not include activities performed from our strength training program.

\section{Godin Leisure-Time Exercise Questionnaire}

Considering a 7-Day period (one week), how many times on the average do you do the following kinds of exercise for more than 15 minutes during your free time (write in each box the appropriate number).

Times Per Week

A) Strenuous Exercise

(Heart Beats Rapidly)

(i.e. running, jogging, squash, roller skating,

vigorous swimming, vigorous long distance bicycling)

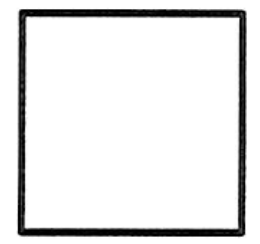

B) Moderate Exercise

(Not Exhausting)

(i.e. fast walking, tennis, easy bicycling,

badminton, easy swimming, popular and folk dancing)

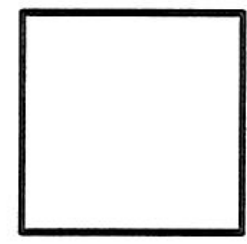

C) Mild Exercise

(Minimal Effort)

(i.e. yoga archery, gardening, house work, bowling, horseshoes, golf, easy walking) 


\section{Appendix B}

\section{PAR-Q+}

\section{The Physical Activity Readiness Questionnaire for Everyone}

Regular physical activity is fun and healthy, and more people should become more physically active every day of the week. Being more physically active is very safe for MOST people. This questionnaire will tell you whether it is necessary for you to seek further advice from your doctor $O R$ a qualified exercise professional before becoming more physically active.

\section{SECTION 1 - GENERAL HEALTH}

\begin{tabular}{|c|c|c|c|}
\hline \multicolumn{2}{|r|}{ Please read the 7 questions below carefully and answer each one honestly: check YES or NO. } & \multirow{2}{*}{ YES } & \multirow{2}{*}{ NO } \\
\hline 1. & Has your doctor ever said that you have a heart condition OR high blood pressure? & & \\
\hline 2. & $\begin{array}{l}\text { Do you feel pain in your chest at rest, during your daily activities of living, OR when you do physical } \\
\text { activity? }\end{array}$ & 遜 & 进 \\
\hline 3. & $\begin{array}{l}\text { Do you lose balance because of dizziness OR have you lost consciousness in the last } 12 \text { months? Please } \\
\text { answer NO if your dizziness was associated with over-breathing (including during vigorous exercise). }\end{array}$ & 毝 & 近 \\
\hline 4. & $\begin{array}{l}\text { Have you ever been diagnosed with another chronic medical condition } \\
\text { (other than heart disease or high blood pressure)? }\end{array}$ & 毝 & 2 \\
\hline 5. & Are you currently taking prescribed medications for a chronic medical condition? & 毝 & 24 \\
\hline 6. & $\begin{array}{l}\text { Do you have a bone or joint problem that could be made worse by becoming more physically active? } \\
\text { Please answer NO if you had a joint problem in the past, but it does not limit your current ability to be } \\
\text { physically active. For example, knee, ankle, shoulder or other. }\end{array}$ & 手 & 2 \\
\hline 7. & Has your doctor ever said that you should only do medically supervised physical activity? & 16.4. & 近 \\
\hline
\end{tabular}

If you answered NO to all of the questions above, you are cleared for physical activity. Go

to Section 3 to sign the form. You do not need to complete Section 2.

> Start becoming much more physically active - start slowly and build up gradually.

> Follow the Canadian Physical Activity Guidelines for your age (www.csep.ca/guidelines).

) You may take part in a health and fitness appraisal.

> If you have any further questions, contact a qualified exercise professional such as a CSEP Certified Exercise Physiologist" (CSEP-CEP) or CSEP Certified Personal Trainer ${ }^{\circ}$ (CSEP-CPT).

> If you are over the age of $45 \mathrm{yrs}$. and NOT accustomed to regular vigorous physical activity, please consult a qualified exercise professional (CSEP-CEP) before engaging in maximal effort exercise.

If you answered YES to one or more of the questions above, please GO TO SECTION 2.

Delay becoming more active if:

, You are not feeling well because of a temporary illness such as a cold or fever - wait until you feel better

, You are pregnant - talk to your health care practitioner, your physician, a qualified exercise professional, and/or complete the PARmed-X for Pregnancy before becoming more physically active $\mathrm{OR}$

> Your health changes - please answer the questions on Section 2 of this document and/or talk to your doctor or qualified exercise professional (CSEP-CEP or CSEP-CPT) before continuing with any physical activity programme. 


\section{Appendix C}

\section{REGINA}

\section{Research Participant Information and Consent Form}

Title of the study: Effects of creatine supplementation dosing strategies on muscle performance.

Researchers: Darren G. Candow, Ph.D. (Principal Investigator), Faculty of Kinesiology and Health Studies, University of Regina, phone: 306-- 585-- 4906, email: Darren.Candow@uregina.ca;; Jennifer Chami, MSc student researcher, email: jenchami@gmail.com

\section{Sponsor: University of Regina (pending)}

24- hour emergency telephone contact: 306-- 209-- 0280

\section{Introduction:}

You are being invited to participate in this research study because we want to compare the effects of different dosages of creatine on muscle strength, endurance, and tasks of functionality (walking speed, balance, hand grip strength) in men and women.

Before you decide to participate, it is important that you understand what the research involves. This consent form will tell you about the study, why the research is being performed, what will happen to you during the study, and the possible benefits, risks, and discomforts.

If you wish to participate, you will be asked to sign this form. Your participation is entirely voluntary, so it is up to you to decide whether or not to participate in this study. If you decide to take part in this study, you are free to withdraw at any time without giving any reasons for your decision and your choice not to participate will not affect your relationship with any of the researchers or institutions conducting the research.

Please take time to read the following information carefully and to discuss it with your family, friends, and doctor or health professional before you decide.

\section{Why is this study being done?}

The age- related loss of muscle strength and muscle endurance that can be performed decreases the ability to perform activities of daily living (i.e., walking, carrying groceries) in aging men and women. Creatine, a nitrogen containing compound found in red meat and seafood may have beneficial effects on aging muscle performance however, the optimal dosage needed to attain these effects is 
unclear. The purpose of this study is to compare the effects of different doses of creatine compared to a placebo (an inactive substance) on muscle strength, endurance and functionality. A total of 48 participants will be involved in this study. Who can participate in this study?

You can participate if you are male or female aged 50 years and older and have not engaged in supervised resistance training for $\geq 6$ weeks prior to the start of the study. In addition, you cannot have preexisting kidney or liver problems, taken medications that affect muscle biology or creatine monohydrate $\leq 12$ weeks prior to the start of the study;; have a history of fragility fractures;; diseases that are known to affect muscle biology (i.e., Crohn's Disease);; suffer from severe osteoarthritis;; or vegetarian.

\section{What does the study involve?}

If you agree to participate in this study, the following will occur:

You will initially be given a questionnaire (Physical Activity Readiness Questionnaire;; PAR- Q+) which assesses whether you are at a health risk for participating in exercise training. If you indicate a possible health risk, you will be given a clearance form (PARMED- $X$ ) to be filled out by your family physician before being permitted to participate in this study. In addition, you will fill out a leisure time exercise questionnaire, which indicates the average number of times that strenuous (i.e., heart beats rapidly), moderate (i.e., not exhausting), and mild exercise (i.e., minimal effort) is performed per week.

Prior to the start of the study, you will be randomized (i.e. assigned by chance by a computer) into one of four groups: Group (1) High-- dose creatine (CR-- H;; 0.3 $\mathrm{g} / \mathrm{kg} /$ day of creatine $+0.1 \mathrm{~g} / \mathrm{kg} /$ day of maltodextrin), (2) Medium-- dose creatine (CR- M;; $0.2 \mathrm{~g} / \mathrm{kg} /$ day of creatine $+0.2 \mathrm{~g} / \mathrm{kg} /$ day of maltodextrin), (3) Low-- dose creatine (CR-- L;; $0.1 \mathrm{~g} / \mathrm{kg} /$ day of creatine $+0.3 \mathrm{~g} / \mathrm{kg} /$ day of maltodextrin) or (4) Placebo (PLA;; $0.4 \mathrm{~g} / \mathrm{kg} /$ day of maltodextrin) for 10 consecutive days. Creatine and placebo will be in powder form and you will be asked to consume this mixed with water and consume it with each meal (i.e., three times throughout the day). Participants will record the amount and time of each drink consumed throughout the day. Neither you nor the researchers will know which group you are in until the end of the study, but we can find out what group you are in if there is an emergency (i.e. an adverse reaction to the creatine or placebo). Due to the nature of the study we might not be able to inform you about your group assignment until 6 months after the study is over (except in the case of an emergency).

All of the groups will participate in a series of exercises before and after the 10 days of supplementation in the Fitness and Lifestyle Centre at the University of Regina and take approximately 45 minutes to complete. Three days before the study you will be shown the exercises and tasks then asked to perform a familiarization trial of strength and endurance as well as the tasks of functionality.

Study measurements: The following measurements will be performed prior to the intervention (i.e. baseline) and after 10 days: 
1 Your muscle strength (1-- RM leg press and chest press

- Your muscle endurance (maximal number of repetitions performed at $80 \%$ and $70 \%$ baseline 1-- RM for the leg press and chest press, respectively)

- Your tasks of functionality (walking speed, balance, hand grip strength).

- We will give you questionnaires about your diet. These questionnaires take about half an hour to complete.

What are the benefits of participating in this study?

You might increase your muscle strength, endurance, balance and walking speed by participating in this study. These benefits are not guaranteed.

\section{What are the possible risks and discomforts?}

Creatine supplementation has been shown on a few occasions to decrease kidney and liver function in individuals with pre- existing kidney or liver disease. If you have any kidney or liver abnormalities, you should not participate in this study.

\section{What are alternatives to the study?}

You do not have to participate in this study to increase muscle strength or balance. You can perform alternative exercises (i.e. free-- body exercises such as push-- ups or chin ups and wall squats). You could also increase your creatine consumption from your diet by consuming more red meat and seafood products instead of receiving creatine supplementation in this study.

\section{What happens if I decide to withdraw?}

Your participation in this research is voluntary. You may withdraw from this study at any time. You do not have to provide a reason. Your relationships with the researchers or the university will not be affected. If you choose to enter the study and then decide to withdraw at a later time, all data collected about you during your enrolment will be retained for analysis.

\section{What happens if something goes wrong?}

In the case of a medical emergency related to the study, you should seek immediate care and, as soon as possible, notify the principal investigator. Inform the medical staff you are participating in a clinical study. Necessary medical treatment will be made available at no cost to you. By signing this document, you do not waive any of your legal rights against the sponsor, investigators or anyone else.

\section{What happens after completion of the study?}

We will inform you of the overall study results after we have analyzed all data.

\section{What will the study cost me?}


You will not be charged for the creatine, placebo, or any research-- related procedures.

You will not be paid for participating in this study. Reimbursement for studyrelated expenses (e.g. travel, parking, meals) is not available.

Will my participation be kept confidential?

In Saskatchewan, the Health Information Protection Act (HIPA) defines how the privacy of your personal health information must be maintained so that your privacy will be respected. Your name will not be attached to any information, nor mentioned in any study report, nor be made available to anyone except the research team. It is the intention of the research team to publish results of this research in scientific journals and to present the findings at related conferences and workshops, but your identity will not be revealed.

\section{Who do I contact if I have questions about the study?}

If you have questions concerning the study you can contact Dr. Darren Candow at 306-- 585-- 4906 or 306-- 209- 0280 (24 hour cell).

If you have any questions about your rights as a research subject or concerns about this study, you may contact the Chair of the University of Regina Research Ethics Board at

(306) 585-- 4775 or email research.ethics@uregina.ca. Out of town participants may call collect.

\section{Consent statement}

- I have read (or someone has read to me) the information in this consent form.

- I understand the purpose and procedures and the possible risks and benefits of the study.

- I have been informed of the alternatives to the study.

- I was given sufficient time to think about it.

- I had the opportunity to ask questions and have received satisfactory answers.

- I am free to withdraw from this study at any time for any reason and the decision to stop taking part will not affect my future relationships at the university.

- I agree to follow the principal investigator's instructions and will tell the principal investigator at once if I feel I have had any unexpected or unusual symptoms.

- I have been informed there is no guarantee that this study will provide any benefits to me.

- I give permission for the use and disclosure of my de-- identified personal health information collected for the research purposes described in this form.

o I understand that by signing this document I do not waive any of my legal rights.

- I will be given a signed and dated copy of this consent form.

- I give permission for my family physician to be informed about my participation in this study if need be: 
D Yes

D No

D I do not have a family physician

D I agree to participate in this study:

Printed name of participant:

Signature

Date

Printed name of person obtaining consent:

Signature

Date 


\section{Appendix D}

\section{Adverse Event Form}

\section{Study Adverse Event Form}

CREATINE SUPPLEMENT STUDY: ADVERSE EVENT FORM

SUBJECT ID\#:

SUBJECT INITIAL:

Describe the adverse event:

(Record diagnosis where available or describe event in as few words as possible.)

Is this event a new event?

Is this event a change/resolution of an ongoing event?

Onset of Adverse Event (date/time):

Resolution of Adverse Event (date/time):

Is this event Serious?

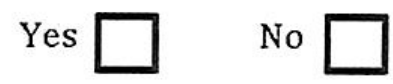

(Results in death, is life threatening, requires hospitalization, results in persistent or significant disability.)

Is this event intermittent?

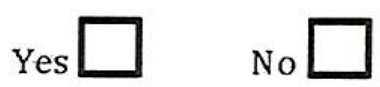

Rate Intensity (severity): Please circle
Mild
Moderate
Severe
Life threatening

2. Is the adverse event still present:

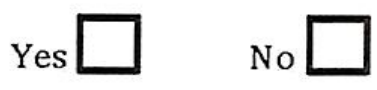

3. Frequency:

4. Relationship to experimental procedure (food, exercise or other procedure): Please circle
Not related
Unlikely
Possible
Probable
Definite 
